Discussion Paper No. 12-046

\title{
Empirical Evaluation of Interest Barrier Effects
}

Daniel Dreßler and Uwe Scheuering

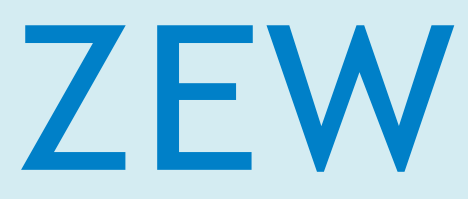

Zentrum für Europäische Wirtschaftsforschung GmbH Centre for European Economic Research 
Discussion Paper No. 12-046

\section{Empirical Evaluation of Interest Barrier Effects}

\section{Daniel Dreßler and Uwe Scheuering}

Download this ZEW Discussion Paper from our ftp server:

http://ftp.zew.de/pub/zew-docs/dp/dp12046.pdf

Die Discussion Papers dienen einer möglichst schnellen Verbreitung von neueren Forschungsarbeiten des ZEW. Die Beiträge liegen in alleiniger Verantwortung der Autoren und stellen nicht notwendigerweise die Meinung des ZEW dar.

Discussion Papers are intended to make results of ZEW research promptly available to other economists in order to encourage discussion and suggestions for revisions. The authors are solely responsible for the contents which do not necessarily represent the opinion of the ZEW. 


\section{Non-Technical Summary}

As of 2008, Germany has severely changed its thin capitalization rule by introducing the so-called interest barrier. This new rule aims at prohibiting tax avoidance of multinational firms by means of cross-border internal loans. For reasons of non-discrimination, the rule is, however, equally attributable on the national level and it is applicable to both internal and external debt. Since its beginning, the German interest barrier has had a very poor reputation as it was believed to distort financing decisions and hereby harm production efficiency.

Four years after its introduction, the time has come to empirically evaluate the interest barrier. In this paper, we trace to what extent the interest barrier impacted firms' financing decisions. We distinguish between national and multinational firms as well as between the effects on internal debt to assets and external debt to assets.

Thin capitalization rules prevent firms from deducting excessive interest expenses from their tax base. Before 2008, the interest on internal debt going beyond 1.5 times the equity of the respective shareholder was not deductible. As of 2008, interest payments exceeding the interest earnings are generally only deductible at the amount of $30 \%$ of EBITDA once the exemption limit of an initial EUR 1 million is exceeded. In our empirical setup, we identify firms which would have been affected by the new interest barrier, had it already been in place in the years 2005 to 2007, i.e. before its actual coming into force. Then we analyze empirically how these firms adjusted their debt to assets ratios and their net interest payments as compared to the control group.

Our regressions show that the interest barrier drove firms to lower their debt to assets ratios and their net interest payments. Opposing its original intention, it seems to be, however, also the national firms which adjusted their capital structure and it was external rather than internal debt which was reduced. Therefore, we conclude that the interest barrier does indeed affect financing decisions, but predominantly not in the intended way and not of the intended firms. In sensitivity analyses, we examine highly leveraged and low profitable firms, which are likely to be subject to the interest barrier. The results suggest a debt-reducing interest barrier effect for these companies as well.

Our empirical evidence does not provide a positive evaluation of the new interest barrier. The legislator might have focused too much on the task of counteracting excessive and abusive internal lending by a few multinationals, whilst disregarding the effects on non-abusive firms. 


\section{Das Wichtigste in Kürze}

Mit der Einführung der sogenannten Zinsschranke hat Deutschland zum Jahr 2008 seine Unterkapitalisierungsregel tiefgreifend geändert. Mit dieser neuen Regelung wird primär das Ziel verfolgt, die von multinationalen Unternehmen durch grenzüberschreitende Kreditvergaben betriebene Steuervermeidung zu bekämpfen. Aus Gründen der Nichtdiskriminierung gilt die Regel jedoch gleichermaßen für rein nationale Unternehmen und für externes ebenso wie für internes Fremdkapital. Von Beginn an hatte die deutsche Zinsschranke einen sehr schlechten Ruf. Sie steht im Verdacht Finanzierungsentscheidungen zu verzerren und somit die Produktionseffizienz zu mindern.

Vier Jahre nach Einführung der Zinsschranke ist die Zeit reif für eine empirisch fundierte Evaluation. Wir untersuchen, inwieweit die Zinsschranke die Finanzierungsentscheidungen von Unternehmen beeinflusst hat. Dabei weisen wir die Einflüsse auf nationale und multinationale Unternehmen sowie auf die externe und interne Fremdkapitalquote jeweils gesondert aus.

Unterkapitalisierungsregeln verhindern bei Unternehmen mit übermäßiger Fremdfinanzierung den steuerlichen Zinsabzug. Vor dem Jahr 2008 waren Zinsen, die sich auf internes Fremdkapital in Höhe von mehr als dem 1,5-fachen des Anteilseignerkapitals bezogen, nicht abziehbar. Seit 2008 hängt die Abziehbarkeit dagegen nicht mehr von der Fremdkapitalquote, sondern von Zinszahlungen ab. So sind die Zinserträge übersteigenden Zinsaufwendungen nun grundsätzlich nur noch in Höhe von 30\% des EBITDA abziehbar, sobald die Freigrenze von einer Million Euro überschritten ist. Wir identifizieren diejenigen Firmen, die von der neuen Zinsschranke getroffen worden wären, wenn diese bereits von 2005 bis 2007, also vor ihrer tatsächlichen Einführung, anwendbar gewesen wäre. Sodann untersuchen wir empirisch, wie solche Firmen im Vergleich zur Kontrollgruppe ihre Fremdkapitalquote und ihre Nettozinszahlungen angepasst haben.

Ganz grundsätzlich hat die Zinsschranke dazu geführt, dass Firmen sowohl ihre Fremdkapitalquote als auch ihre Nettozinszahlungen gesenkt haben. Entgegen der Zinsschrankenintention haben jedoch auch die nationalen Firmen diesen Schritt vollzogen und es wurde außerdem eher externes als internes Fremdkapital heruntergefahren. Somit wirkt die Zinsschranke tatsächlich auf Finanzierungsentscheidungen, jedoch weder in der beabsichtigten Art und Weise, noch ausschließlich bei den anvisierten Firmen. In Sensitivitätsanalysen werden besonders hoch verschuldete Firmen sowie Unternehmen mit niedriger Profitabilität untersucht, da diese mit hoher Wahrscheinlichkeit von der Zinsschranke betroffen sind. Die Ergebnisse deuten auch für diese Gruppe auf schuldenreduzierende Zinsschrankeneffekte hin.

Insgesamt stellen die von uns gefundenen empirischen Erkenntnisse der Zinsschranke kein gutes Zeugnis aus. Der Gesetzgeber hat sich vermutlich zu sehr darauf konzentriert, wie er die exzessive grenzüberschreitende Kreditvergabe einiger weniger multinationaler Unternehmen bekämpfen kann und dabei die Effekte auf unbescholtene Firmen vernachlässigt. 


\title{
Empirical Evaluation of Interest Barrier Effects ${ }^{1}$
}

\author{
Daniel Dreßler and Uwe Scheuering \\ Centre for European Economic Research $(\mathrm{ZEW})^{2}$
}

July 2012

\begin{abstract}
:
We analyze the impact of changes in thin capitalization rules on corporations' capital structure. Thin capitalization rules prevent firms from deducting excessive interest expenses from their tax base. As of 2008, Germany has severely changed its thin capitalization rule by targeting interest payments instead of debt to equity ratios. The new rule has primarily been introduced to prohibit tax avoidance by multinationals. For reasons of non-discrimination, the rule is, however, equally attributable on the national level and it is applicable to both internal and external financing. The theoretical and analytical literature has brought forward many arguments stating that the new interest barrier is harmful to firms, distorting their financing decisions. Four years after its introduction, the time has come to empirically evaluate the interest barrier. The DAFNE database serves as our source of reference. We differentiate by firm characteristics, by industry and by kind of debt. We find that the interest barrier drove firms to lower their debt to assets ratios and their net interest payments. Opposing its original intention, it was, however, also the national firms which adjusted their capital structure, and it was external rather than internal debt which was reduced. Thus, the interest barrier does indeed affect financing decisions, but predominantly not in the intended way and not of the intended firms. In sensitivity analyses we examine highly leveraged and low profitable firms, which are likely to be subject to the interest barrier. The results suggest a debt-reducing interest barrier effect for these companies as well.
\end{abstract}

Keywords: $\quad$ Capital Structure, Corporate Taxation, Interest Barrier, Empirical Analysis, Firm-Level Data

JEL-Classification: F23, H25, H32

\footnotetext{
${ }^{1}$ We thank Holger Daske and Johannes Voget for helpful comments. Financial support by the German Science Foundation (DFG) is gratefully acknowledged. All remaining errors are ours.

${ }^{2}$ Centre for European Economic Research (ZEW), L7,1, D-68161 Mannheim, Germany, dressler@zew.de, scheuering@zew.de, +49 6211235377.
} 


\section{Introduction}

Not without a lack of irony, Homburg (2007) calls the interest barrier an unprecedented tax innovation. Even before its introduction in 2008, the German interest barrier had a very poor scientific reputation. Based on analytical considerations, it is supposed to distort financing decisions, thus harming production efficiency. It is said to drive into bankruptcy even those firms which have no intentions of abusive tax evasion whatsoever. According to Homburg (2007), the German interest barrier combines maximal economic damage with minimal fiscal utility. The numerous critical articles on the German regulation did, however, not prevent Italy from introducing a very similar rule in the same year 2008 .

Thin capitalization rules prevent firms from deducting interest from their tax base if certain conditions are met. Before 2008, the amount of (non-)deductible interest was determined by a firm's debt to equity ratio. The interest on internal debt going beyond 1.5 times the equity of the respective shareholder was not deductible. As of 2008, the deductibility of interest no longer depended on the ratio, but on interest payments. Generally speaking, interest payments exceeding the interest earnings are only deductible at the amount of $30 \%$ of EBITDA once the exemption limit of an initial EUR 1 million is exceeded. The new interest barrier rule covers all sources of interest and, unlike the previous rule, not only internal but also external debt. It has primarily been introduced to prohibit tax avoidance by multinationals. For reasons of non-discrimination, the rule is equally attributable on the national level. Non-deductible interest is recorded in an interest carryforward. Figure 1 below illustrates the functioning of the new interest barrier.

Homburg (2007) is not the only - convincing - analytical paper which severely criticizes the interest barrier. Blaufus and Lorenz (2009), Bolik, Fuest and Ortmann-Babel (2010), Eilers (2007), Endres (2007), Herzig and Bohn (2007), Hey (2007), Musil and Volmering (2008), Stangl and Rödder (2007) Töben (2007) and Welling (2007) draw similarly negative conclusions. German politicians have reacted to this critique by slightly relaxing the interest barrier in 2009, when they retroactively increased the exemption amount from EUR 1 million to EUR 3 million and also enlarged the tolerance range of the so-called escape clause, comparing the firm's leverage to the group's leverage.

Four years after its introduction, the time has come to empirically evaluate the interest barrier. Affected firms might either be struck by the interest barrier or might have taken evasive actions. Our empirical estimations are based on Bureau van Dijk's DAFNE database, which is a detailed subgroup of the Amadeus database covering German companies. We differentiate by firm characteristics, by industry and by different kinds of debt. 
Figure 1: Interest Barrier - Legal Scheme

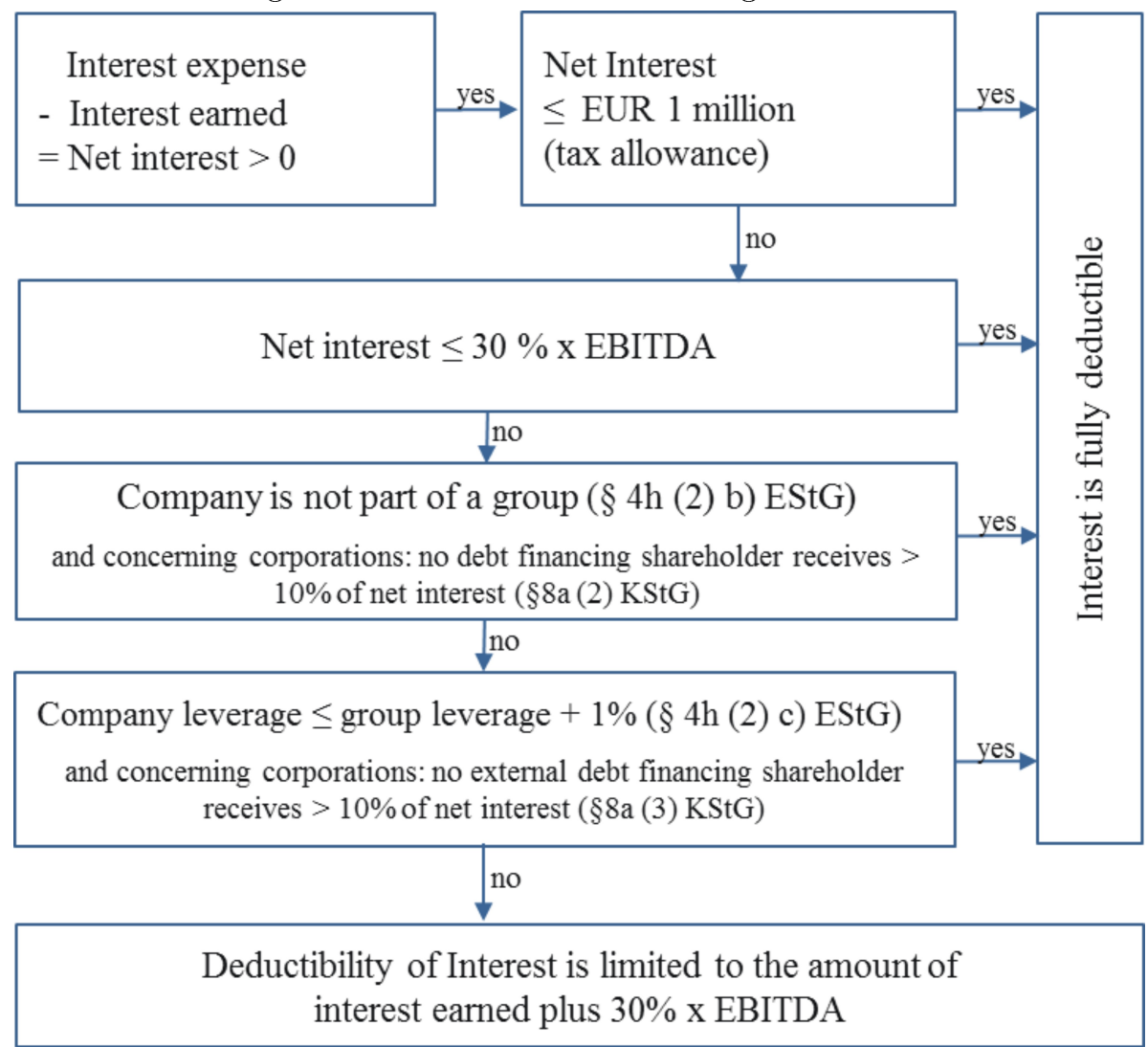

Cf. Winkeljohann and Fuhrmann (2007). As of 2009, the tax allowance was increased to EUR 3 million and the company leverage could exceed the group leverage by $2 \%$.

We find that the interest barrier made firms lower their debt to assets ratios. Opposing its original intention, it was, however, also the national firms which adjusted their capital structure. In robustness checks, we find interest barrier effects for highly leveraged firms and for companies with a low profitability.

The remainder of the paper is organized as follows. In the next section we present a literature review. Thereafter, the effects of the thin capitalization legislation are worked out analytically in Section 3. This serves as the basis for our development of hypotheses in Section 4. Descriptive statistics are provided in Section 5, followed by the empirical approach in Section 6 and results in Section 7. Finally, Section 8 concludes. 


\section{Literature Review}

Ever since Modigliani and Miller $(1958,1963)$ published their theory of the capital structure of a firm, the tax advantage of debt financing in contrast to equity financing has been widely discussed in the literature. Modigliani and Miller argue that debt financing is more advantageous than equity financing since interest expenses are tax deductible. However, they also highlight that there are a lot of non-tax reasons influencing the optimal financing decision. As a result, they reject the idea that $100 \%$ debt financing is usually the best choice. Further analytical research strengthened this position and revealed that it might not always be beneficial to finance corporate undertakings with debt. Myers (1977) for example, argues that an already existing asset stock should rather be financed with a higher percentage of debt compared to new growth opportunities.

Following the analytical approaches, multiple authors tried to show these effects empirically. MacKie-Mason (1990) as well as Graham (1999) find positive effects of corporate tax rates on leverage by focusing on data about primary seasoned offerings. Gordon and Lee (2001 and 2007) reveal a much larger effect that is particularly strong for small and for very large firms but not for medium-sized firms. Additionally, Desai, Foley and Hines (2004) can show that the effect varies with the source of debt. Their study on U.S. firms yields a higher responsiveness to tax-rate differences of internal debt compared to external debt. Huizinga, Laeven and Nicodème (2008) also provide support for the international debt and profit shifting of multinationals. The corporate tax rate effect on financing decisions has been summarized in a literature review by Graham (2003) and in a meta study by Feld, Heckemeyer and Overesch (2011).

Rajan and Zingales (1995), Graham (1999), Alworth and Arachi (2001) and Overesch and Voeller (2010) do not only focus on the positive effect of corporate tax rates on the debt level, but also try to identify a proposed negative effect of high personal taxes on interest. ${ }^{3}$ Each of these studies is based on a different dataset and covers an international context. All of them clearly identify the proposed negative effect.

However, there are also studies that fail to identify either of the above mentioned effects or that stress other effects as relatively more important. Taub (1975) for example, finds a counterintuitive negative effect of higher corporate tax rates on debt financing. Myers (1984) postulates that the past literature provided no convincing evidence on corporate

\footnotetext{
${ }^{3}$ Miller (1977) argues that, at the margin, a negative effect of personal taxation might negate the corporate tax advantage of debt financing, because most tax systems favour dividend income to interest income. De Angelo and Masulis (1980) implement an interior leverage equilibrium model considering the interaction of corporate and personal taxes.
} 
taxes increasing the leverage. Lemmon, Roberts and Zender (2008) find that firm-specific leverage remains constant over a very long period of time, i.e. more than 20 years, concluding that the majority of variation in capital structure is time-invariant and that much of this variation is unaccounted for by existing empirical specifications.

When it comes to the financial effects of tax policy, one may wonder whether the measures to counter the effects described above were successful. Haufler and Runkel (2008), Weichenrieder and Windischbauer (2008) as well as Buettner, Overesch, Schreiber and Wamser (2008) all focus on the question of whether thin capitalization rules result in a reduction of internal debt and whether this increases fiscal revenues. Wamser (2008) focus on the introduction of the German thin capitalization rule in 1994 and its amendments in 2001 and 2004. All of these empirical studies find evidence on a significant reduction of internal debt following the introduction of a thin capitalization rule. However, they do not show that this reduction also resulted in a reduction of overall debt. They rather suggest that internal debt was substituted with external debt resulting in no increase in tax revenues.

As mentioned in the introduction, the emergence of the German interest barrier rule in 2007 was predominantly criticized in the German tax literature for being too far-reaching. Three elements of the interest barrier rule are heavily criticized. First of all, the rule is said to overshoot the mark because not only internal but also external debt financing is limited (cf. Hey (2007), Homburg (2007)). Second, the interest barrier rule is seen as being harmful, especially to companies in financial distress. It is argued that the interest barrier rule can result in high taxation for highly leveraged companies having low earnings. It might force companies which are in a loss situation before consideration of the rule into paying taxes, thus making their situations even worse. The interest barrier is therefore seen as reinforcing a crisis (cf. Endres (2007), Grotherr (2008), Herzig and Bohn (2007), Hey (2007), Köhler (2007), Schwarz (2008)). Third, the so-called escape-clause is heavily criticized. It allows companies to escape the interest barrier rule if they can prove that the German company does not deviate from the equity-quota of the group, i.e. that the German business is not highly leveraged compared to the overall group. Dörfler and Vogl (2007), Endres (2007), Ganssauge and Mattern (2008), Grotherr (2008), Thiel (2007) and Welling (2007), however, see this equity test as highly complex and as bearing high administrative costs. Focusing on legal aspects, Führich (2007), Hornig (2007) and Musil and Volmering (2008) argue that the interest barrier rule does not comply with EU-law and the German constitution. 
Empirical enquiries of the interest barrier rule in Germany have, so far, mainly focused on two aspects. Bolik, Fuest and Ortmann-Babel (2010) as well as Herzig, Lochmann and Liekenbrock (2008) asked companies about their perception of the interest barrier rule and whether they are being harmed by it. Bolik, Fuest and Ortmann-Babel (2010) show that most companies conceptually reject the rule and the newly-introduced loss carryforward restrictions, and that companies expect a higher tax burden as a result of the new interest barrier rule. Herzig, Lochmann and Liekenbrock (2008) show that $43 \%$ of the companies expect to be harmed by the rule. The second aspect that has been traced empirically is which companies will be harmed by the rule. Though the expected numbers differ between 150 and 1511 companies, Bach and Buslei (2009) as well as Blaufus and Lorenz (2009) expect the rule to be particularly harmful to large companies.

Even when the rule was adjusted in 2009, criticism continued. Rödding (2009) and Lenz, Doerfler and Adrian (2010) argue that the equity-quota computation is still problematic and demand the conversion of the newly increased exemption limit of EUR 3 million into a tax allowance. Additionally, Herzig and Liekenbrock (2010) stress problems with the EBITDA-carryover.

\section{General Analytics}

Firms might lower their debt to assets ratios if the advantage of debt financing decreases. We illustrate this by comparing the net present value of a debt financed and an equity financed investment.

If the investor provides equity to the firm, the net present value of the investment is given by

$$
N P V_{E}=E X_{0}+\sum_{t=1}^{n} \frac{\left(I_{t}-E X_{t}-D E P_{t}\right)\left(1-\tau_{c}\right)\left(1-\tau_{s}\right)}{\left[1+i\left(1-\tau_{i}\right)\right]^{t}},
$$

where $E X_{0}$ is the amount of investment, $I_{t}$ and $E X_{t}$ are the income and expenses in period $t, D E P_{t}$ is the amount of depreciation, $i$ is the interest rate, and $\tau_{c}$ and $\tau_{s}$ are the tax rates for corporate profits on the firm and shareholder level. $\tau_{i}$ is the tax rate on interest earnings. If the investor instead chooses to provide capital in the form of debt, the net present value is

$$
N P V_{D}=N P V_{E}+\sum_{t=1}^{n} \frac{\gamma I N T_{t}\left(1-\tau_{s}\right) \tau_{c}+I N T_{t}\left(\tau_{s}-\tau_{i}\right)}{\left[1+i\left(1-\tau_{i}\right)\right]^{t}}
$$


where $I N T_{t}$ are interest expenses for debt provided by the investor and $0<\gamma<1$ is the fraction of interest payments that is deductible from the corporate tax base. ${ }^{4} \gamma$ equals 1 if no thin capitalization rules exist, but is $<1$ if the company is affected by the interest barrier, for example. As the deductiblity of interest payments leads to a lower taxation than in the equity financed investment where dividends are not tax-deductible, we see in equation (2) that the net present value of a debt financed investment is always greater than the net present value of an equity financed investment as long as some interest expenses are deductible from the corporate tax base, in particular as long as $\gamma>\frac{\tau_{i}-\tau_{s}}{\left(1-\tau_{s}\right) \tau_{c}}$. This means that firms generally have a tax-induced incentive to use debt rather than equity as a means of financing. This result was first developed by Modigliani and Miller (1963). Opposing this tax advantage of debt financing, there are other determinants of the capital structure choice like legal constraints, risk considerations and the availability of debt, leading to the fact that we do not exclusively observe debt financed investments. The optimal fraction of debt, however, is supposed to be positively affected by the tax advantage. We are particularly interested in the effect of $\gamma$. Equation (2) shows that the tax advantage of debt increases in $\gamma$. Thus, assuming that the introduction of the interest barrier in Germany in 2008 leads to a decrease of $\gamma$, the relative advantage of debt financing over equity financing decreases and therefore the application of debt in the years after the reform is generally supposed to decrease.

To find out for which firms the new interest barrier is more restrictive than the old debt to assets rule with its 1.5 internal debt to equity safe haven, we compare the interest expenses that are non-deductible under both rules on a company level. We first take a look at the old rule. The non-deductible interest expenses $(N D I)$ are given by

$$
N D I_{\text {old }}:=\left\{\begin{aligned}
\left(1-\frac{1.5}{\lambda D / E}\right) i \lambda D, & \text { if }>0 \\
0, & \text { otherwise }
\end{aligned}\right.
$$

where $i$ is the interest rate payable for debt, $E$ is the equity of the considered company and $\lambda$ is the fraction of total debt that is labeled as internal debt. As a result, the term in parantheses is the fraction of internal debt for which interest expenses are non-deductible

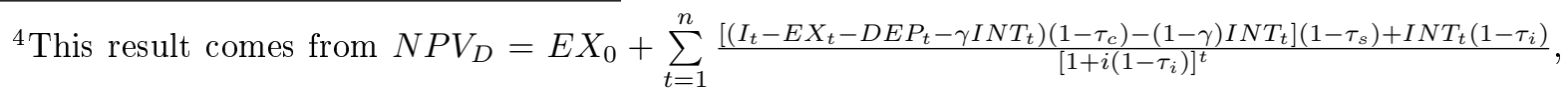
where only $\gamma \cdot I N T_{t}$ are deductible from the corporate tax base and $(1-\gamma) I N T_{t}$, the part that is not deductible, is only deducted from the personal tax base. In addition, the interest payments received by the investor are fully taxed on the personal level. 
under the old rule. Under the new rule, the amount of non-deductible interest is

$$
N D I_{\text {new }}:=\left\{\begin{aligned}
i(D-V)-0.3 \cdot E B I T D A, & \text { if }>0 \\
0, & \text { otherwise. }
\end{aligned}\right.
$$

Here, $V$ are the lendings of the company given to other parties and EBITDA are the earnings before interest and depreciation which is the sum of earnings before interest, $E B I T$, and the amount of depreciation in the considered period, $D E P .{ }^{5}$ In Figure 2 we show the non-deductible interest expenses as a percentage of total assets under the old (dashed lines) and the new rule (solid lines) as a function of the debt to assets ratio $\frac{D}{A} \cdot{ }^{6}$ We see that the slope of $N D I_{\text {old }}$ is higher than the one of $N D I_{\text {new }}$.

Figure 2: $N D I_{\text {old }}$ and $N D I_{\text {new }}$ as functions of $\frac{D}{A}$ for different $\lambda \mathrm{s}$ and $r \mathrm{~s}$

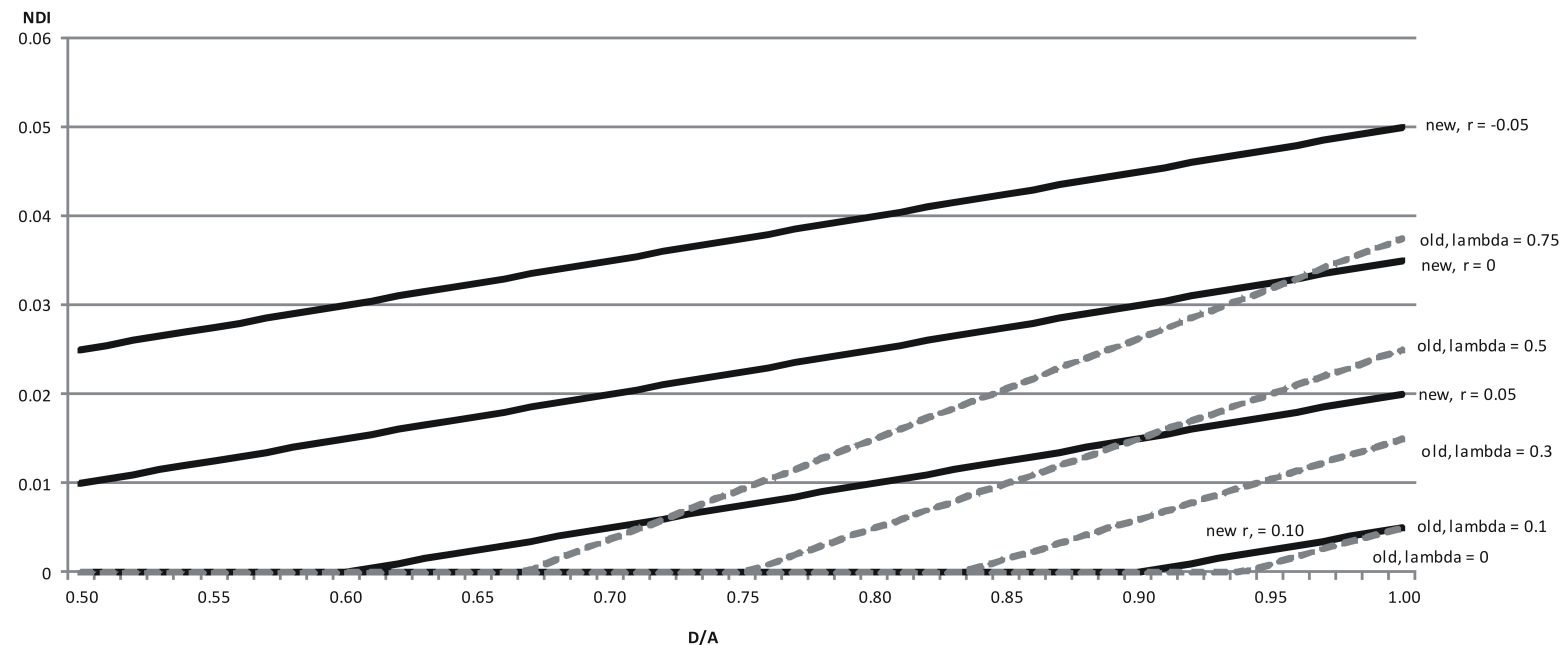

Dashed lines are non-deductible interest payments $(N D I)$ in per cent of total assets under the old rule and solid lines are non-deductible interest payments in per cent of total assets under the new rule.

For given values of the profitability $r$, which is defined as EBIT divided by total assets and determines $N D I_{\text {new }}$ and for $\lambda$, determining $N D I_{\text {old }}$, we sometimes find an intersection of both lines. From this critical value for the debt to assets ratio onwards, the old rule leads to a higher amount of non-deductible expenses than the new rule. This is the case where $r$ and $\lambda$ are relatively high, meaning profitable firms with lots of internal debt. For firms with a lower profitability which mainly have external debt in their balance sheet, $N D I_{\text {new }}$ is likely to be higher than $N D I_{\text {old }}$. The analytical form for this critical value of the debt to assets ratio for which both rules lead to the same amount of non-deductible

\footnotetext{
${ }^{5}$ We do not mention the exemptions of the new rule in this analytical part for the sake of simplicity. In addition, we assume that the interest rate is the same for both borrowing and lending.

${ }^{6} V=0$ and the ratio of depreciation to total assets $\frac{D E P}{A}=0.05$ in this example.
} 
interest expenses is given by

$$
\begin{aligned}
& N D I_{\text {new }} \geq N D I_{\text {old }} \\
& \Leftrightarrow \quad \frac{D}{A} \begin{cases}\leq \frac{1.5-\frac{V}{A}+0.3\left(\frac{r}{i}+\frac{D E P}{A \cdot i}\right)}{\lambda+0.5-1}, & \text { if } N D I_{\text {old }}>0 \\
\geq \quad \frac{V}{A}+0.3\left(\frac{r}{i}+\frac{D E P}{A \cdot i}\right), & \text { if } N D I_{\text {old }}=0 .\end{cases}
\end{aligned}
$$

If all interest expenses are deductible under the old rule, the debt to assets ratio, from which $N D I_{\text {new }}>0$, increases in profitability, the lending-fraction and the depreciationfraction of assets. In addition, it decreases in the interest rate. If the old rule also restricts interest deductibility, the new rule is stricter than the old one if the debt to assets ratio is below a critical value depending on the same variables and, in addition, on $\lambda$. Solving for $r$ leads to

$$
\begin{aligned}
& N D I_{\text {new }} \geq N D I_{\text {old }} \\
& \Leftrightarrow \quad r \leq\left\{\begin{aligned}
\frac{i}{0.3}\left[(1-\lambda-1.5) \frac{D}{A}-\frac{V}{A}+1.5\right]-\frac{D E P}{A}, & \text { if } N D I_{\text {old }}>0 \\
\frac{i}{0.3}\left[\frac{D}{A}-\frac{V}{A}\right]-\frac{D E P}{A}, & \text { if } N D I_{\text {old }}=0 .
\end{aligned}\right.
\end{aligned}
$$

If the old rule does not restrict interest deductibility, the critical value for $r$ increases in the debt to assets ratio and the interest rate. In addition, it decreases in the lendingfraction and depreciation-fraction of assets. This is because the interest barrier rule looks at net interest expenses and compares them to earnings before depreciation. If some interest expenses are non-deductible under the old rule, the critical value for $r$ also depends on the fraction of internal debt $\lambda$. Then, it decreases in $\frac{D}{A}$ if $\lambda$ is fixed. Figure 3 shows the run of the critical-r-curve as a function of $\frac{D}{A}$ for different $\lambda \mathrm{s}^{7}$ If $\lambda=0$, all interest expenses are deductible under the old rule because it only triggered internal debt. The result is a strictly increasing critical value of $r$ in $\frac{D}{A}$. If $\lambda>0$, the curve forms a kink. For $\lambda=0.3$, for example, the critical value for $r$ is the same for $\frac{D}{A}=0.7$ and $\frac{D}{A}=1.0$ and equals 0.067 . This means the difference of $N D I_{\text {new }}$ and $N D I_{\text {old }}$ is the same for the two debt to assets ratios and $r=0.067$. The difference between these two points is that $N D I_{\text {new }}=N D I_{\text {old }}=0$ if $\frac{D}{A}=0.7$ and $N D I_{\text {new }}=N D I_{\text {old }}>0$ if $\frac{D}{A}=1.0$. We can summarize by saying that, in our example, the new rule denies more interest expenses to be deductible than the old rule if $\frac{D}{A}$ is between 0.7 and 1.0 and the profitability is lower than $6.7 \%$, i.e. if the company is located in the grey area under the $r$-curve. Descriptive

\footnotetext{
${ }^{7} \frac{V}{A}=0$ and $\frac{A f A}{A}=0.05$ in this example.
} 
statistices for $\frac{D}{A}, r, \lambda$ and $\frac{D E P}{A}$ are shown in Table 3 of Section 5 .

Figure 3: Critical rentability as function of $\frac{D}{A}$ for different $\lambda \mathrm{s}$

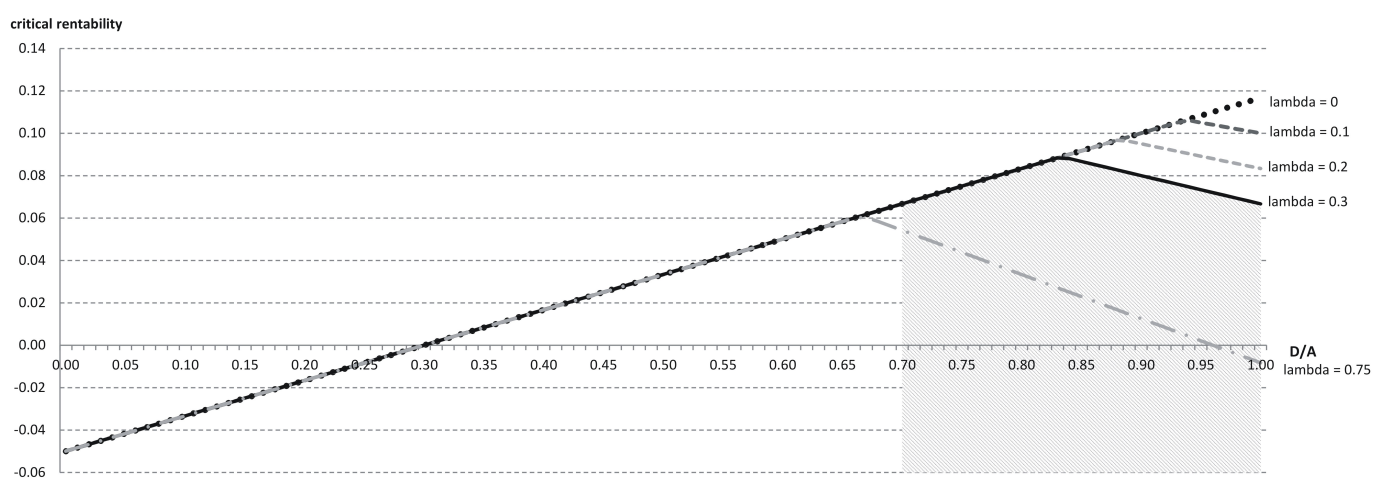

We can conclude that only specific firms are supposed to suffer more from the new interest barrier than from the old debt to equity rule. As we can see in Figures 2 and 3, the interest barrier is especially harmful for firms with a low profitability whereas firms with an average profitability are likely to remain unaffected by the reform or even benefit from the new rule. This corresponds to findings of Blaufus and Lorenz (2009). In addition, the old rule was more harmful for firms having a high fraction of internal debt to total debt. Therefore, in our empirical analysis, we divide the dataset into different groups of firms comparing their respective reactions after the reform.

\section{Development of Hypotheses}

When the new interest barrier was introduced in 2008, the German legislator first and foremost aimed at one specific goal: putting an end to the tax-induced abusive internal cross-border lending of multinational companies. ${ }^{8}$ In order to avoid conflicts with the European Court of Justice, however, the new anti-avoidance rule could not specifically target multinationals, but had to treat cross-border lending and purely national lending in the same way. As shown above, the interest barrier differentiates neither by the number of countries involved, nor whether internal or external debt is at hand. Thus, companies can neither avoid the rule by expanding or concentrating their business nor by switching between external and internal lending.

\footnotetext{
${ }^{8}$ Cf. the official justification for the interest barrier, BR-Drucks. 220/07 (2007), p. 53.
} 
The actions which can actually be taken by companies in order to avoid unfavorable consequences of the interest barrier lead to results very much in line with the intention of the legislator. A company can cut the leverage in the high tax country, it can grant more loans in order to increase its interest earnings or it can aim at achieving a higher EBITDA without adjusting its leverage. All of these measures taken by a company generate and secure the tax base in the high tax country applying the interest barrier. In this paper we aim at analyzing whether the companies affected by the new interest barrier in Germany lowered their leverage. Even though we carry out an empirical analysis on the micro level, our approach also allows for conclusions regarding to what extent the legislator reached its goals and to what extent it caused collateral damage by influencing and punishing companies he did not genuinely aim at.

The basic technical idea behind our identification method is the following: we identify firms which would have been affected by the new interest barrier if it had already been in place in the years 2005 to 2007, i.e. before its actual coming into force in 2008. Then we analyze empirically how these firms adjusted their debt to assets ratios as compared to the control group. It is a necessity to split the treatment group from the control group based on their characteristics before the introduction of the interest barrier, because the information after it already comprehends the firms' reactions.

Our very first hypothesis is very general. It builds on the assumption that firms try to avoid non-deductible interest. Even though non-deductible interest is recorded in an interest carryforward, its existence does not decisively influence the hypothesis. As compared to an immediate deduction, the carryfoward brings a net present value disadvantage and its applicability is uncertain, especially for struggling firms. Once the interest barrier has come into force, companies can calculate to what extent they are negatively affected by the legislation and adjust their capital structure accordingly. Firms arriving at the conclusion that they are not affected by the interest barrier, by contrast, have no particular reason to adjust their leverage. These firms serve as the control group. Of course, there are other effects influencing the optimal leverage such as the decline of the corporate tax rate or macroeconomic criteria influencing the interest rate. ${ }^{9}$ Given that such effects are the same to both of the analyzed groups, they do not prevent the sound identification of an interest barrier effect. Thus, we state hypothesis H1:

H 1. After the introduction of the new interest barrier, the hypothetically ex ante hit firms lowered their leverage. This holds especially true concerning firms which are more severely affected by the new interest barrier than by the previous rule.

\footnotetext{
${ }^{9}$ As of 2008 , for example, the German corporate income tax rate was lowered from $25 \%$ to $15 \%$.
} 
The interest barrier was set up to prohibit legal but unpleasant tax avoidance by multinational firms. The provision of loans from subsidiaries in low-tax countries such as Ireland to company units in high-tax countries such as Germany should be prevented. Interest is taxed where it is received but reduces the tax base in the high-tax country. If multinationals actually set up such financial structures with the primary intention of saving taxes, they should easily be able to adjust them if necessary. Based on this rationale, even though the interest barrier does not explicitly distinguish between multinational and national lending, the cross-border constructions can be expected to be more elastic. Put differently, stronger adjustments of the capital structure can be expected by multinational firms because the - repealed - tax advantage was one of their primary reason for the high leverage. National firms, by contrast, might very well have other predominant reasons for using debt such as the sheer absence of alternatives to external financing. Regardless of their desire to lower their leverage once the interest barrier is in place, these national firms might not, or at least only to a lower extent, be able to do so. Therefore, our second hypothesis is the following:

H 2. After the introduction of the new interest barrier, companies belonging to multinational groups lowered their leverage more strongly.

When companies decide to apply debt financing, they still have a choice between internal debt and external debt. While internal debt stems from shareholders or other members of the group, external debt is provided by banks or similar lenders. The effect of the interest barrier introduction might very well differ between these two kinds of debt financing. The interest barrier first and foremost targets tax-abusive internal debt financing. In order to prevent evasive constructions it does, however, not distinguish between interest from internal or external debt. Before the new interest barrier came into force in 2008, only internal debt was relevant for the calculation of the debt to equity ratio. Therefore, external debt has become less attractive with the introduction of the new interest barrier. Given that external debt was previously hardly relevant, in the course of the interest barrier introduction we should see a relatively stronger reduction in external rather than in internal debt. Thus, we state our third hypothesis:

H 3. After the introduction of the new interest barrier, companies reduced more strongly their external debt than their internal debt.

Some debt financing is permissible. The new interest barrier accounts for this by granting a basic tax allowance and by admitting the deductibility of interest expenses to the amount of interest earned plus $30 \%$ of EBITDA. By introducing the interest barrier, the 
legislator did not aim at generally prohibiting debt financing, but at preventing excessive tax-induced leveraging. With our fourth hypothesis, we investigate to what extent especially those firms targeted by the new interest barrier actually reduced their debt to assets ratio. The logic behind our hypothesis is not that such highly leveraged firms reduce their debt because they are eager to fulfill the wish of the legislator, rather they are supposed to adjust it because they are the ones which are most severely hit by the new interest barrier. Given that we refer to the total leverage in this hypothesis and given that most of the debt in our data is external debt, the treatment group is generally more negatively affected by the new interest barrier than by the previous thin capitalization rule. It is therefore likely to adjust its financial structure. Thus, we suppose in our fourth hypothesis:

H 4. After the introduction of the new interest barrier, especially the $5 \%$ most highly leveraged companies reduced their debt to assets ratios.

In Section 3, we have analytically worked out that firms with a rather low profitability are more likely to be affected by the new interest barrier than profitable firms. As could be seen above, the lower a firm's profitability, the more adverse is the new interest barrier as compared to the previous thin capitalization rule. Those firms facing a more severe rule than in the past, i.e. for which debt has become less attractive than before, are the ones which are most likely supposed to lower their leverage. In line with Blaufus and Lorenz (2009), companies with an average or even above-average profitability, however, are not negatively affected by the interest barrier rule. When focusing solely on the effect of the new legislation in the form of the interest barrier, we can state the following hypothesis:

$\mathbf{H}$ 5. After the introduction of the new interest barrier, especially the $5 \%$ least profitable companies reduced their debt to assets ratios.

\section{Data and Descriptive Statistics}

We look at the development of the debt to assets ratios and the net interest payments to assets ratios of 25,751 German corporations between 2005 and 2010 in an unbalanced panel. Our analysis considers all debt, internal debt and external debt one by one. In order to analyze the effects of the introduction of the interest barrier we put firms into different groups according to their non-deductible interest payments concerning the old and the new rule, according to their leverage and according to their profitability. We further control for the firms' tangibility, profitability, former losses and the number of employees. 
All these data are provided by the DAFNE-database by Bureau van Dijk, a subsample of the AMADEUS-database containing detailed information of German companies needed to compute the non-deductible expenses. We use information from unconsolidated statements for all corporations with total assets of more than EUR 1 million, hence concentrating on medium-sized and large fims. We drop firms with implausible values for equity, total assets, tangible assets, EBIT, EBITDA, liabilities, profitability, tangibility and interest payments. For the purpose of our analysis, we exclude firms operating in the agricultural, mining and finance sector. In addition, we use statutory corporate tax rates to control for tax rate effects on the companies' leverage. Table 1 defines all variables used in our regression analysis. Table 2 shows frequencies and absolute numbers of firms in different groups. In our sample, 487 companies, i.e. $1.89 \%$ of all companies, would have been treated by the new interest barrier in all three years before the introduction if it had been applicable since 2005. For 345 firms, i.e. $4.38 \%$ of the applicable companies, the new rule would have been more harmful than the old rule. ${ }^{10}$ In addition, Table 3 provides summary statistics of the applied variables.

\footnotetext{
${ }^{10}$ The sample for computing if the new rule is more harmful than the old one is a bit smaller because we need additional information about the internal leverage. $4.38 \%=345 / 7,878$, cf. Table 4 for the sample size.
} 
Table 1: Variable definitions

debt to assets
internal debt to assets
external debt to assets
net interest payments
to assets
internal net interest
payments to assets
external net interest
payments to assets
reform

total debt divided by total assets, measured in percentagepoints $(0.01=$ one percent $)$

internal debt divided by total assets, measured in percentage-points $(0.01=$ one percent $)$

external debt divided by total assets, measured in percentage-points $(0.01=$ one percent $)$

total net interest payments divided by total assets, measured in percentage-points $(0.01=$ one percent $)$

internal net interest payments divided by total assets, measured in percentage-points $(0.01=$ one percent $)$

external net interest payments divided by total assets, measured in percentage-points $(0.01=$ one percent $)$

dummy variable, 1 if observation is made in the years $2008-2010$, zero if observation is made in years $2005-2007$

treated dummy variable, 1 if company would have had nondeductible interest expenses according to the new interest barrier in all three years before the reform

dependent dummy variable, 1 if company has no shareholder and no subsidiary with a participation rate of at least $25 \%$

stricter dummy variable, 1 if company would have had more nondeductible interest expenses according to the new interest barrier compared to the old thin capitalization rule in all three years before the reform

high lev dummy variable, 1 if company was in the group of firms with the $5 \%$ highest average leverage in the three years before the reform

low prof dummy variable, 1 if company was in the group of firms with the $5 \%$ lowest average profitability in the three years before the reform

tangibility

profitability tangible assets divided by total assets, measured in percentage-points $(0.01=$ one percent $)$

EBITDA divided by total assets, measured in percentagepoints $(0.01=$ one percent $)$ 
Table 1: Variable definitions (continued)

\begin{tabular}{ll}
\hline \hline loss carryforward & $\begin{array}{l}\text { dummy variable, } 1 \text { if the profit before taxes was negative in } \\
\text { the year before the observation }\end{array}$ \\
str & statutory tax rate, measured in percentage-points $(0.01=$ \\
& one percent $)$ \\
str * loss carryfwd & interaction between str and loss carryforward \\
ln employees & logarithm of number of employees \\
$\frac{D E P}{A}$ & amount of depreciation divided by total assets, measured in \\
& percentage-points (0.01 = one percent) \\
$i$ & interest rate computed by dividing interest paid by total \\
& debt, measured in percentage-points (0.01 = one percent) \\
$r$ & profitability defined as EBIT divided by total assets, meas- \\
& ured in percentage-points (0.01 = one percent) \\
& fraction of internal debt to total debt, measured in \\
& percentage-points (0.01 = one percent)
\end{tabular}

The general source of the variables is the DAFNE-database provided by Bureau van Dijk. Some variables are built by own computations using the information from DAFNE. Variables with names combining the above variables by $*$ are interactions of the repective variables. The statutory tax rates are derived from the IBFD Global Corporate Tax Handbooks.

Table 2: Relative frequencies and numbers of firms in different groups

\begin{tabular}{llll}
\hline \hline group & all firms & nationals & multinationals \\
\hline treated & $1.89(487)$ & $1.43(334)$ & $6.58(153)$ \\
stricter & $4.38(345)$ & $3.30(214)$ & $9.39(131)$ \\
high leveraged & $3.86(1077)$ & $3.98(1018)$ & $2.56(59)$ \\
high leveraged dependent & $3.56(913)$ & $3.68(854)$ & n.a. \\
high leveraged independent & $0.04(11)$ & $0.05(11)$ & n.a. \\
low profitable & $4.69(1262)$ & $4.53(1115)$ & $6.54(147)$ \\
low profitable dependent & $4.39(1077)$ & $4.18(932)$ & n.a. \\
low profitable independent & $0.06(13)$ & $0.06(13)$ & n.a. \\
\hline \hline
\end{tabular}

The table contains relative frequencies of firms in different groups in the regression samples in per cent. Absolute numbers are depicted in parentheses. Treated means that the company would have had non-deductible interest expenses triggering the new interest barrier in all three years before the reform. Independent means that the company has no $25 \%$ shareholder or subsidiary. Stricter means that the company would have had more non-deductible interest expenses based on the new interest barrier compared to the old rule in all three years before the reform. High leveraged means that the firm had one of the $5 \%$ highest average debt to assets ratios before the reform. Low profitable means that the firm had one of the $5 \%$ lowest average profitabilities before the reform. 
Table 3: Summaries

\begin{tabular}{|c|c|c|c|c|c|}
\hline \multicolumn{6}{|c|}{ all companies } \\
\hline Variable & Obs. & Mean & Std. Dev. & Min & Max \\
\hline debt to assets & 88451 & 0.6204 & 0.2402 & 0.0002 & 1 \\
\hline internal debt to assets & 65802 & 0.1613 & 0.2017 & 0 & 0.9985 \\
\hline external debt to assets & 65802 & 0.4711 & 0.2399 & 0 & 0.9994 \\
\hline net interest payments to assets & 88333 & 0.0074 & 0.0267 & -2.8348 & 1.2843 \\
\hline internal net interest payments to assets & 29225 & 0.0065 & 0.0139 & -0.0119 & 1.2064 \\
\hline external net interest payments to assets & 29225 & -0.0024 & 0.0265 & -1.2019 & 0.3309 \\
\hline reform & 88451 & 0.5788 & 0.4938 & 0 & 1 \\
\hline treated & 88451 & 0.0204 & 0.1414 & 0 & 1 \\
\hline treated $*$ reform & 88451 & 0.0117 & 0.1074 & 0 & 1 \\
\hline dependent & 88451 & 0.9890 & 0.1041 & 0 & 1 \\
\hline dependent $*$ reform & 88451 & 0.5724 & 0.4947 & 0 & 1 \\
\hline stricter & 29649 & 0.0451 & 0.2074 & 0 & 1 \\
\hline stricter $*$ reform & 29649 & 0.0250 & 0.1561 & 0 & 1 \\
\hline high lev & 94320 & 0.0323 & 0.1767 & 0 & 1 \\
\hline high lev * reform & 94320 & 0.0187 & 0.1354 & 0 & 1 \\
\hline high lev * dependent & 87519 & 0.0303 & 0.1713 & 0 & 1 \\
\hline high lev $*$ reform $*$ dep & 87519 & 0.0179 & 0.1326 & 0 & 1 \\
\hline low prof & 92938 & 0.0428 & 0.2024 & 0 & 1 \\
\hline low prof $*$ reform & 92938 & 0.0234 & 0.1513 & 0 & 1 \\
\hline low prof $*$ dependent & 86247 & 0.0406 & 0.1973 & 0 & 1 \\
\hline low prof $*$ reform $*$ dep & 86247 & 0.0227 & 0.1490 & 0 & 1 \\
\hline tangibility & 88451 & 0.2581 & 0.2538 & 0 & 0.9984 \\
\hline profitability & 88451 & 0.1285 & 0.1374 & -0.2950 & 0.6358 \\
\hline loss carry forward & 88451 & 0.1617 & 0.3682 & 0 & 1 \\
\hline str & 88451 & 0.3450 & 0.0417 & 0.3095 & 0.3943 \\
\hline str $*$ loss carryfwd & 88451 & 0.0557 & 0.1278 & 0 & 0.3943 \\
\hline str $*$ tangibility & 88451 & 0.0891 & 0.0890 & 0 & 0.3931 \\
\hline ln employees & 88451 & 4.5997 & 1.2950 & 0 & 12.2138 \\
\hline$\frac{D E P}{A}$ & 88451 & 0.0472 & 0.3457 & -0.0071 & 84.3892 \\
\hline$i^{1}$ & 84333 & 0.0233 & 0.0374 & 0 & 7 \\
\hline$r$ & 88451 & 0.0824 & 0.1732 & -6.6173 & 4.5382 \\
\hline$\lambda$ & 65802 & 0.2405 & 0.2595 & 0 & 1 \\
\hline
\end{tabular}




\section{Empirical Approach}

In order to test our hypotheses we run regressions using a panel approach. We rely on the variation over time to analyze if and how firms altered their leverage after the introduction of the interest barrier. We apply a difference in difference approach in order to capture different reactions for different kinds of firms. Our baseline regression equation is

$$
\begin{aligned}
{\text { debt to } \text { asset }_{i t}} & \beta_{1} \cdot \text { treated }_{i}+\beta_{2} \cdot \text { reform }_{i t}+\beta_{3} \cdot \text { treated }_{i} * \text { reform }_{i t} \\
& +\boldsymbol{X}_{i t} \boldsymbol{\beta}+\delta_{i}+\delta_{t}+\delta_{j}+\delta_{j t}+\epsilon_{i t}
\end{aligned}
$$

where debt to assets $_{i t}$ is total debt divided by total assets. The variable treated $_{i}$ is a dummy that equals one if the considered firm would have been affected by the new interest barrier in all three years before its introduction. ${ }^{11}$ Re form $_{i t}$ is a dummy indicating by the value of one if the observation is made after the introduction of the interest barrier. Treated $_{i} *$ reform $_{i t}$ is the interaction of these two variables. $\boldsymbol{X}$ is the matrix of timevarying firm-specific control variables. Subscripts $i, j$ and $t$ denote the company, the industry and the year. Therefore, $\delta_{i}, \delta_{j}$ and $\delta_{t}$ are company-, industry- and time-fixed effects, $\delta_{j t}$ is an industry-time-fixed effect capturing industry-specific developments of the

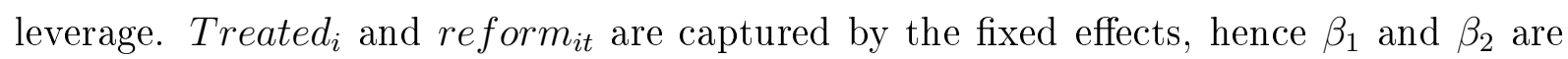
not reported. The coefficient of treated $_{i} *$ reform $_{i t}$ shows if treated firms changed their debt to assets ratios in a different way than other firms. For the effects on firms which are more severe hit by the new interest barrier than by the old rule, we replace treated tr $_{i}$ stricter $_{i}$. This variable equals one if treated $_{i}$ is one and non-deductible interest expenses according to the new rule were higher than the those according to the old rule in all three years before the reform. ${ }^{12}$ This approach can be used to test H1. Considering H2, we split the sample into national companies and multinational companies. H3 is tested with the same equation replacing the dependent variable by internal and external debt to assets.

To test H4, we replace the treatment dummy by the variable high lev indicating if a company had an average debt to assets ratio before the reform that was higher than the 95 percent quantile of all considered firms. In addition, we introduce a three-way interaction to examine if highly leveraged firms which might be affected by the new interest barrier

\footnotetext{
${ }^{11}$ For the labeling if a company is treated or not, we generally use the scheme of Figure 1 . The escape clause, comparing the firm's leverage to the group's leverage is, however, disregarded. Concerning the group membership, we distinguish by the existence or non-existence of a $25 \%$ subsidiary and/or a $25 \%$ shareholder.

${ }^{12}$ The non-deductible amount according to the old rule is calculated by comparing the firm's internal debt to the firm's equity. All interest expenses for such debt exceeding 1.5 times the equity are labeled as non-deductible.
} 
reacted differently from firms which do not have to worry about non-deductible expenses because they are independent and thus not affected by the new rule. Therefore the equation changes to

$$
\begin{aligned}
\text { debt to assets }_{i t} & =\beta_{1} \cdot \text { high lev }_{i}+\beta_{2} \cdot \text { reform }_{i t}+\beta_{3} \cdot \text { dependent }_{i} \\
& +\beta_{4} \cdot \text { high lev }_{i} * \text { reform }_{i t}+\beta_{5} \cdot \text { high lev }_{i} * \text { dependent }_{i} \\
& +\beta_{6} \cdot \text { reform }_{i t} * \text { dependent }_{i}+\beta_{7} \cdot \text { high lev }_{i} * \text { reform }_{i t} * \text { dependent }_{i} \\
& +\boldsymbol{X}_{i t} \boldsymbol{\beta}+\delta_{i}+\delta_{t}+\delta_{j}+\delta_{j t}+\epsilon_{i t} .
\end{aligned}
$$

A positive $\beta_{4}$ means that independent highly leveraged firms have increased their leverage after the reform compared to other firms with lower debt to assets ratios. This coefficient is generally not expected to be significant because independent firms are never affected by the new interest barrier. For dependent firms, $\beta_{4}$ and $\beta_{7}$ must be added to see the whole effect. In addition, $\beta_{6}$ plus $\beta_{7}$ is the difference in reaction between highly leveraged dependent and independent firms. If these two coefficients are jointly significant, there is a specific interest barrier effect for potentielly affected firms. We use this three-way interaction approach to capture the fact that highly leveraged firms might generally reduce their debt to assets ratios over time to return to their individually aspired ratio. ${ }^{13}$ The same kind of analysis is used to test $\mathrm{H} 5$ replacing the dummies for highly leveraged firms by a binary variable which is one if a company belongs to those firms with the 5 percent lowest average profitablities before the reform.

\section{Regression Results}

Our regressions deal one by one with the hypotheses derived in Section 4 . The first three result tables, Tables 4 to 6 , cover the issues outlined in hypotheses H1 to H3, while Table 7 and Table 8 trace H4 and H5. Table 4 is based on all firms, whereas Table 5 focuses on national firms and Table 6 focuses on multinationals. The same differentiation is maintained in Tables 7 and 8. The structure within the tables is always the same: The columns to the left of a table analyze the effects on total debt to assets, the columns in the middle focus on the effects on internal debt to assets and the columns to the right present the effects on external debt to assets. All regressions are difference-in-difference approaches showing the effects of the interest barrier introduction on financing decisions of different kinds of companies. We use a fixed effects estimator in order to capture unobserved firm, industry and time specific effects. The Annex shows additional results.

\footnotetext{
$\overline{{ }^{13} \mathrm{Cf} \text {. Weichenrieder and Windischbauer }}$ (2008).
} 
Table 4: Baseline Regressions, all firms

\begin{tabular}{|c|c|c|c|c|c|c|}
\hline & \multicolumn{2}{|c|}{ all debt } & \multicolumn{2}{|c|}{ internal debt } & \multicolumn{2}{|c|}{ external debt } \\
\hline & (1) & $(2)$ & $(3)$ & $(4)$ & $(5)$ & $(6)$ \\
\hline treated $*$ reform & $\begin{array}{c}-0.0122^{* *} \\
(0.0059)\end{array}$ & & $\begin{array}{c}-0.0016 \\
(0.0072)\end{array}$ & & $\begin{array}{c}-0.0119 \\
(0.0079)\end{array}$ & \\
\hline stricter $*$ reform & & $\begin{array}{c}-0.0144^{*} \\
(0.0077)\end{array}$ & & $\begin{array}{c}0.0114 \\
(0.0081)\end{array}$ & & $\begin{array}{c}-0.0259^{* * *} \\
(0.0092)\end{array}$ \\
\hline tangibility & $\begin{array}{c}0.0396 * * \\
(0.0195)\end{array}$ & $\begin{array}{c}0.0363 \\
(0.0350)\end{array}$ & $\begin{array}{l}-0.0189 \\
(0.0237)\end{array}$ & $\begin{array}{c}0.0188 \\
(0.0409)\end{array}$ & $\begin{array}{c}0.0397 \\
(0.0252)\end{array}$ & $\begin{array}{c}0.0086 \\
(0.0393)\end{array}$ \\
\hline profitability & $\begin{array}{c}-0.1892^{* * *} \\
(0.0071)\end{array}$ & $\begin{array}{c}-0.1848 * * * \\
(0.0116)\end{array}$ & $\begin{array}{c}-0.0838 * * * \\
(0.0088)\end{array}$ & $\begin{array}{c}-0.1089 * * * \\
(0.0134)\end{array}$ & $\begin{array}{c}-0.1048^{* * *} \\
(0.0085)\end{array}$ & $\begin{array}{c}-0.0801^{* * *} \\
(0.0119)\end{array}$ \\
\hline loss carryforward & $\begin{array}{c}0.1585^{* * *} \\
(0.0093)\end{array}$ & $\begin{array}{c}0.1246^{* * *} \\
(0.0148)\end{array}$ & $\begin{array}{c}0.0293^{* *} \\
(0.0116)\end{array}$ & $\begin{array}{c}0.0566^{* * *} \\
(0.0176)\end{array}$ & $\begin{array}{c}0.1064^{* * *} \\
(0.0115)\end{array}$ & $\begin{array}{c}0.0616 * * * \\
(0.0162)\end{array}$ \\
\hline str $*$ loss carryfwd & $\begin{array}{c}-0.3822^{* * *} \\
(0.0270)\end{array}$ & $\begin{array}{c}-0.2883^{* * *} \\
(0.0430)\end{array}$ & $\begin{array}{c}-0.0606^{*} \\
(0.0336)\end{array}$ & $\begin{array}{c}-0.1306 * * \\
(0.0508)\end{array}$ & $\begin{array}{c}-0.2569 * * * \\
(0.0334)\end{array}$ & $\begin{array}{c}-0.1391^{* * *} \\
(0.0466)\end{array}$ \\
\hline str $*$ tangibility & $\begin{array}{c}-0.1485^{* * *} \\
(0.0446)\end{array}$ & $\begin{array}{l}-0.1049 \\
(0.0825)\end{array}$ & $\begin{array}{c}-0.1044^{*} \\
(0.0577)\end{array}$ & $\begin{array}{c}-0.1677^{*} \\
(0.0993)\end{array}$ & $\begin{array}{l}-0.0528 \\
(0.0588)\end{array}$ & $\begin{array}{c}0.0673 \\
(0.0922)\end{array}$ \\
\hline ln employees & $\begin{array}{c}0.0192^{* * *} \\
(0.0027)\end{array}$ & $\begin{array}{c}0.0212^{* * *} \\
(0.0038)\end{array}$ & $\begin{array}{c}-0.0083^{* * *} \\
(0.0030)\end{array}$ & $\begin{array}{c}-0.0081^{*} \\
(0.0042)\end{array}$ & $\begin{array}{c}0.0278^{* * *} \\
(0.0029)\end{array}$ & $\begin{array}{c}0.0285^{* * *} \\
(0.0037)\end{array}$ \\
\hline observations & 88451 & 29649 & 65802 & 27665 & 65802 & 27665 \\
\hline companies & 25751 & 7878 & 20892 & 7661 & 20892 & 7661 \\
\hline$R^{2}$ & 0.1011 & 0.0971 & 0.0199 & 0.0347 & 0.0533 & 0.0533 \\
\hline
\end{tabular}

The dependent variable is debt to assets. Treated $*$ reform is an interaction of dummies which equals 1 if the observation is made after the introduction of the interest barrier and the firm would have been treated by the new rule in all three years before the introduction. A negative sign of the coefficient means that the difference between the leverage before and after the reform is lower for treated firms compared to companies not treated by the new interest barrier. In regression 2 we use the interaction stricter * reform to analyze if firms, for which the new interest barrier would have been stricter than the old rule in all three years before the reform, reduced their debt to assets ratios more strongly or increased it to a lower extent than other firms. Other variables are described in Table 1 . Regressions 3 and 4 repeat regressions 1 and 2 using internal debt to assets as the dependent variable, regressions 5 and 6 use external debt to assets. Regressions include company and industry-year-fixed effects. Observations of German corporations between 2005 and 2010 stem from the DAFNE-database. Robust standard errors, clustered at the subsidiary level, are shown in parentheses. ${ }^{*}$ denotes significance at the $10 \%$-level, ${ }^{* *}$ at the $5 \%$-level and ${ }^{* * *}$ at the $1 \%$-level.

In columns (1) and (2) of Table 4, the ratio of total debt to assets serves as the dependent variable. The variable treated is a dummy that equals one for those firms which would have been affected by the new interest barrier in 2005, 2006 and in 2007 if it had been in place not only from 2008 onwards but already in the three previous years. This variable is captured by the firm-fixed effects. Being affected means that the interest barrier prevents the immediate deductibility of at least some interest expenses. The variable reform is a dummy that equals one for those observations that occur after the introduction of the interest barrier. This variable is captured by the year-fixed effects. The interaction of these two variables, treated $*$ reform, shows if the difference between the leverage before and after the reform is lower or higher for affected firms compared to unaf- 
fected companies. The negative and significant coefficient of treated $*$ reform, amounting to -0.0122 , means that after the introduction of the interest barrier, those hypothetically affected firms lowered their debt to assets ratios more strongly or increased it less strongly than the control group. When interpreting the result, one has to keep in mind that we control for firm and industry-year-fixed effects. For example, if the control group lowered its debt to assets ratio after the reform by ten percentage points, the treatment group would have lowered it by 12.2 percentage points. Given that we focus on the size of the change, it can, however, not be seen from the coefficient if the decrease was bigger or the increase was smaller. In either way, the negative coefficient confirms our hypothesis $\mathrm{H} 1$, because firms concerned with the interest barrier chose, on average, a relatively lower debt to assets ratio after its introduction compared to other firms.

In the second sentence of hypothesis H1, we suppose that the lowered leverage should be observable especially concerning firms which are more severely affected by the new interest barrier than by the previous rule. The binary variable stricter equals one for firms for which in all three years 2005, 2006 and 2007, the hypothetically applied interest barrier would have led to more non-deductible interest than the previous rule which was in place at that time. The significant coefficient of the interaction effect stricter $*$ reform -0.0144 indicates that firms which could expect to suffer more from the interest barrier than from the ratio-based thin capitalization rule supposedly lowered their debt to assets ratios more strongly than the control group. This confirms the second sentence in hypothesis H1.

As can be seen by looking at Table 4 as a whole, columns (3) and (4) show the results for the approaches outlined above using internal debt to assets as the dependent variable and columns (5) and (6) do so using external debt to assets as the dependent variable. Based on these general regressions, there is no significant impact of the interest barrier on the ratio of internal debt to assets. This can be seen from the fact that none of the crucial coefficients treated $*$ reform and stricter $*$ reform in columns (3) and (4) is significant.

Turning to the effect on external debt to assets, the results presented in columns (5) and (6) paint a different picture. It seems that firms reacted to the introduction of the interest barrier predominantly with their external debt. The coefficient of treated $*$ reform in column (5) shows the expected sign but fails to be significant. The crucial coefficient stricter * reform in column (6), however, clearly confirms hypothesis H3: After the introduction of the new interest barrier, companies reduced their external debt more strongly than their internal debt. By comparing the results in columns (5) and (6) to those in columns (3) and (4), we see that the affected companies did not significantly differ in adjusting their internal debt to assets ratios compared to non-affected firms. 
Their external debt to assets ratio adjustment, however, clearly differs from the one of the control group if the new interest barrier rule is more severe than the previous thin capitalization rule for the considered company. Those firms significantly reduced their external leverage after the reform compared to the control group. This result corresponds to the effects on all debt presented in column (2).

The control variables generally show the expected effects. The positive and sometimes also significant coefficient of tangibility can be explained by the fact that companies having lots of collateral can more easily and cheaply get loans and thus increase their leverage. Profitability shows a negative and significant coefficient, which means that profitable companies can reduce their leverage due to their ability of internally financing by means of retained earnings. The positive and significant coefficient of loss carry forward indicates that companies which made losses in the past need to raise debt to pay their dues and to keep their businesses running. The number of employees negatively impacts internal debt but positively affects the use of external debt. This is plausible, because, while some kind of debt is required by all kind of firms, a certain firm size may boost the ability to tap external sources. Overesch and Voeller (2010) use the interactions between loss carryforward and str and, in addition, str and tangibility in order to show that the postive tax effect on the debt to assets ratio decreases for firms with high non-debt tax shields. We find the same expected negative effects of both of these interactions on the total, internal and external leverage. ${ }^{14}$ All of the control variables presented here are included in all of the regressions shown in the tables to follow. As they remain qualitatively unchanged, these control variables are not always explicitly reported.

Table 9 in the Appendix is very similar to Table 4 presented above. It differs, however, concerning the requirement of being treated before the interest barrier introduction. While in the above regressions the binary variable was one only if the firm was hypothetically affected in all three years 2005, 2006 and 2007, in the regressions shown in Table 9 it suffices if the company was hypothetically affected in at least one of the three years. The results of this sensivity analysis in Table 9 are qualitatively generally the same as those from Table 4 discussed above. Tables 10 and 11 in the Appendix are analogue robustness checks for the results discussed below.

Table 4 shows results of regressions including all firms. In our second hypothesis H2, however, we suppose that multinationals and national firms showed different debt to assets reactions in face of the new interest barrier. In order to be able to evaluate this

\footnotetext{
${ }^{14}$ The result tables do not show coefficients for str, because the variation of this variable is the same for all considered companies and thus captured by the time-fixed effects.
} 
hypothesis, we split our sample into those firms which are purely national (cf. Table 5) and those belonging to a multinational group (cf. Table 6). Depending on the regression setup, only about $10 \%$ to $20 \%$ of the firms in our sample are multinationals, whereas $80 \%$ to $90 \%$ are national firms.

The results presented in Table 5 refer to national companies. They are qualitatively comparable to those of all firms presented and discussed above. In some cases, the significance or the size effects are higher than in the overall analysis, which indicates that it was mainly the national firms which reacted to the new interest barrier rule. For reasons of brevity, we do not discuss the results of Table 5 one by one, but only provide an overview. More detailed explanations of the coefficients can be achieved by referring to the discussion of Table 4. All in all, the results indicate that those national firms which are affected by the new interest barrier more strongly reduced their total debt to assets ratios than the control group. The specific reactions do not refer to the ratio of internal debt to assets, but they can be traced to the ratio of external debt to assets. This can be seen from the insignificant coefficient in column (4) as compared to the significant coefficients in column (6) of Table 5. Table 10 in the Appendix serves as a robustness check of Table 5 by reducing the requirement of being considered a treated national firm if it was hypothetically affected by the interest barrier at least once instead of three consecutive times between 2005 and 2007. The results presented in Table 10 are qualitatively very similar to those presented in Table 5.

Table 6 deals exclusively with multinational companies. As outlined above, there are not too many multinationals available in our sample. A look at the whole Table 6 shows that in only one case a crucial variable is (at the 10 percent level) significant, whereas all other coefficients are insignificant. The weakly significant coefficient of stricter * reform does not show the expected negative sign and does not prove to stay significant in robustness checks. We conclude from Table 6 that, contrary to the expectations expressed in hypothesis H2, multinationals did not show particularly strong reactions. Our results rather indicate that multinationals did not significantly change their debt to assets ratios, whereas the national companies did show such interest barrier-induced adjustments. Table 11 in the Appendix serves as a robustness check for the regression results dealing with multinationals. Table 11 defines the treated and stricter variable like Tables 9 and 10 . There, these variables already change to one if the company is affected in at least one of the three years before the reform. In Table 11 we find negative effects on all debt and external debt. These results differ from the ones presented in Table 6. However, the conclusion concerning H3 remains unchanged. Multinationals did not significantly reduce their internal leverage, although such a reduction was intended by the new interest barrier. 
Table 5: Baseline Regressions, nationals

\begin{tabular}{|c|c|c|c|c|c|c|}
\hline & \multicolumn{2}{|c|}{ all debt } & \multicolumn{2}{|c|}{ internal debt } & \multicolumn{2}{|c|}{ external debt } \\
\hline & (1) & $(2)$ & $(3)$ & (4) & $(5)$ & $(6)$ \\
\hline treated $*$ reform & $\begin{array}{c}-0.0153^{* *} \\
(0.0068)\end{array}$ & & $\begin{array}{c}-0.0051 \\
(0.0083)\end{array}$ & & $\begin{array}{c}-0.0150 \\
(0.0093)\end{array}$ & \\
\hline stricter $*$ reform & & $\begin{array}{c}-0.0240^{* * *} \\
(0.0090)\end{array}$ & & $\begin{array}{c}0.0018 \\
(0.0100)\end{array}$ & & $\begin{array}{c}-0.0280^{* * *} \\
(0.0104)\end{array}$ \\
\hline tangibility & $\begin{array}{c}0.0407^{* *} \\
(0.0200)\end{array}$ & $\begin{array}{c}0.0468 \\
(0.0367)\end{array}$ & $\begin{array}{l}-0.0111 \\
(0.0244)\end{array}$ & $\begin{array}{c}0.0379 \\
(0.0443)\end{array}$ & $\begin{array}{c}0.0316 \\
(0.0263)\end{array}$ & $\begin{array}{l}-0.0039 \\
(0.0427)\end{array}$ \\
\hline profitability & $\begin{array}{c}-0.1903^{* * *} \\
(0.0074)\end{array}$ & $\begin{array}{c}-0.1756^{* * *} \\
(0.0123)\end{array}$ & $\begin{array}{c}-0.0808 * * * \\
(0.0095)\end{array}$ & $\begin{array}{c}-0.1054^{* * *} \\
(0.0147)\end{array}$ & $\begin{array}{c}-0.1069 * * * \\
(0.0092)\end{array}$ & $\begin{array}{c}-0.0740^{* * *} \\
(0.0131)\end{array}$ \\
\hline loss carryforward & $\begin{array}{c}0.1525^{* * *} \\
(0.0097)\end{array}$ & $\begin{array}{c}0.1281^{* * *} \\
(0.0163)\end{array}$ & $\begin{array}{l}0.0247^{*} \\
(0.0126)\end{array}$ & $\begin{array}{c}0.0604^{* * *} \\
(0.0203)\end{array}$ & $\begin{array}{c}0.1059 * * * \\
(0.0126)\end{array}$ & $\begin{array}{c}0.0610^{* * *} \\
(0.0183)\end{array}$ \\
\hline str $*$ loss carryfwd & $\begin{array}{c}-0.3641^{* * *} \\
(0.0281)\end{array}$ & $\begin{array}{c}-0.2957^{* * *} \\
(0.0473)\end{array}$ & $\begin{array}{l}-0.0545 \\
(0.0365)\end{array}$ & $\begin{array}{c}-0.1513^{* * *} \\
(0.0586)\end{array}$ & $\begin{array}{c}-0.2479 * * * \\
(0.0364)\end{array}$ & $\begin{array}{c}-0.1252^{* *} \\
(0.0527)\end{array}$ \\
\hline str $*$ tangibility & $\begin{array}{c}-0.1788^{* * *} \\
(0.0453)\end{array}$ & $\begin{array}{c}-0.1706^{* *} \\
(0.0865)\end{array}$ & $\begin{array}{c}-0.1279^{* *} \\
(0.0596)\end{array}$ & $\begin{array}{c}-0.2244^{* *} \\
(0.1077)\end{array}$ & $\begin{array}{l}-0.0624 \\
(0.0607)\end{array}$ & $\begin{array}{c}0.0656 \\
(0.0995)\end{array}$ \\
\hline ln employees & $\begin{array}{c}0.0163^{* * *} \\
(0.0029)\end{array}$ & $\begin{array}{c}0.0168^{* * *} \\
(0.0044)\end{array}$ & $\begin{array}{c}-0.0100 * * * \\
(0.0032)\end{array}$ & $\begin{array}{c}-0.0102^{* *} \\
(0.0047)\end{array}$ & $\begin{array}{c}0.0259^{* * *} \\
(0.0032)\end{array}$ & $\begin{array}{c}0.0267^{* * *} \\
(0.0041)\end{array}$ \\
\hline observations & 79278 & 23905 & 57340 & 22098 & 57340 & 22098 \\
\hline companies & 23427 & 6483 & 18655 & 6276 & 18655 & 6276 \\
\hline$R^{2}$ & 0.1095 & 0.1092 & 0.0224 & 0.0427 & 0.0566 & 0.0577 \\
\hline
\end{tabular}

The dependent variable is debt to assets. Treated $*$ reform is an interaction of dummies which equals 1 if the observation is made after the introduction of the interest barrier and the firm would have been treated by the new rule in all three years before the introduction. A negative sign of the coefficient means that the difference between the leverage before and after the reform is lower for treated firms compared to companies not affected by the new interest barrier. In regression 2 we use the interaction stricter * reform to analyze if firms, for which the new interest barrier would have been stricter than the old rule in all three years before the reform, reduced their debt to assets ratios more strongly or increased it to a lower extent than other firms. Other variables are described in Table 1 . Regressions 3 and 4 repeat regressions 1 and 2 using internal debt to assets as the dependent variable, regressions 5 and 6 use external debt to assets. Regressions include company and industry-year-fixed effects. Observations of German corporations not being a member of a multinational group between 2005 and 2010 stem from the DAFNE-database. Robust standard errors, clustered at the subsidiary level, are shown in parentheses. * denotes significance at the $10 \%$-level, ${ }^{* *}$ at the $5 \%$-level and ${ }^{* * *}$ at the $1 \%$-level.

In contrast to Tables 5 and 6 , the consideration of Table 10 and Table 11 indicates that both national and multinational firms adjusted their leverage after the reform. Based on these robustness checks we cannot reject H2. The treatment group in Table 11 consists of firms which are not necessarily affected by the new interest barrier after the reform given that it suffices to be hypothetically affected only once to be a member of the treatment group. Therefore, on the one hand, based on what we find in Table 6, one cannot expect to find any significant effects for this group. On the other hand, such firms might be able to adjust their financing structure more appropriately than those serving as the treatment group in Table 6 . This second aspect might explain why we find reactions for multinational companies only in Table 11. 
Table 6: Baseline Regressions, multinationals

\begin{tabular}{lcc|cccc}
\hline \hline & \multicolumn{2}{c}{ all debt } & \multicolumn{2}{c|}{ internal debt } & \multicolumn{2}{c}{ external debt } \\
\hline & $(1)$ & $(2)$ & $(3)$ & $(4)$ & $(5)$ & $(6)$ \\
\hline treated $*$ reform & -0.0133 & & 0.0033 & & -0.0107 & \\
& $(0.0113)$ & & $(0.0131)$ & & $(0.0142)$ & \\
stricter $*$ reform & & -0.0035 & & $0.0234^{*}$ & & -0.0235 \\
& & $(0.0135)$ & & $(0.0129)$ & & $(0.0170)$ \\
tangibility & 0.1284 & 0.0271 & -0.0198 & -0.0742 & 0.1111 & 0.1011 \\
& $(0.0858)$ & $(0.1166)$ & $(0.0945)$ & $(0.1221)$ & $(0.0858)$ & $(0.1082)$ \\
profitability & $-0.1755^{* * *}$ & $-0.2214^{* * *}$ & $-0.0967^{* * *}$ & $-0.1233^{* * *}$ & $-0.0920^{* * *}$ & $-0.1042^{* * *}$ \\
& $(0.0229)$ & $(0.0311)$ & $(0.0229)$ & $(0.0313)$ & $(0.0214)$ & $(0.0276)$ \\
loss carryforward & $0.1666^{* * *}$ & $0.0997^{* * *}$ & 0.0361 & 0.0221 & $0.1004^{* * *}$ & $0.0734^{* *}$ \\
& $(0.0307)$ & $(0.0360)$ & $(0.0293)$ & $(0.0345)$ & $(0.0294)$ & $(0.0354)$ \\
str $*$ loss carryfwd & $-0.4119^{* * *}$ & $-0.2310^{* *}$ & -0.0436 & -0.0011 & $-0.2810^{* * *}$ & $-0.2152^{* *}$ \\
& $(0.0891)$ & $(0.1039)$ & $(0.0847)$ & $(0.0999)$ & $(0.0856)$ & $(0.1029)$ \\
str $*$ tangibility & -0.0898 & 0.1361 & -0.1272 & 0.0117 & 0.0596 & 0.0937 \\
& $(0.2189)$ & $(0.2846)$ & $(0.2383)$ & $(0.3026)$ & $(0.2213)$ & $(0.2669)$ \\
ln employees & $0.0337^{* * *}$ & $0.0357^{* * *}$ & -0.0031 & -0.0018 & $0.0366^{* * *}$ & $0.0348^{* * *}$ \\
& $(0.0062)$ & $(0.0067)$ & $(0.0074)$ & $(0.0085)$ & $(0.0072)$ & $(0.0082)$ \\
\hline observations & 9173 & 5744 & 8462 & 5567 & 8462 & 5567 \\
companies & 2324 & 1395 & 2237 & 1385 & 2237 & 1385 \\
$R^{2}$ & 0.1123 & 0.1380 & 0.0604 & 0.0803 & 0.0852 & 0.1024 \\
\hline \hline
\end{tabular}

The dependent variable is debt to assets. Treated $*$ reform is an interaction of dummies which equals 1 if the observation is made after the introduction of the interest barrier and the firm would have been treated by the new rule in all three years before the introduction. A negative sign of the coefficient means that the difference between the leverage before and after the reform is lower for treated firms compared to companies not affected by the new interest barrier. In regression 2 we use the interaction stricter * reform to analyze if firms, for which the new interest barrier would have been stricter than the old rule in all three years before the reform, reduced their debt to assets ratios more strongly or increased it to a lower extent than other firms. Other variables are described in Table 1 . Regressions 3 and 4 repeat regressions 1 and 2 using internal debt to assets as the debendent variable, regressions 5 and 6 use external debt to assets. Regressions include company and industry-year-fixed effects. Observations for German corporations being a member of a multinational group between 2005 and 2010 stem from the DAFNE-database. Robust standard errors, clustered at the subsidiary level, are shown in parentheses. * denotes significance at the $10 \%$-level, ${ }^{* *}$ at the $5 \%$-level and ${ }^{* * *}$ at the $1 \%$-level.

In sum, the first three result tables yield three conclusions. First, confirming H1, after the introduction of the new interest barrier, the hypothetically ex ante hit firms, and especially those which are more severely affected by the new interest barrier, lowered their leverage. Second, concerning H2, our results in the robustness checks differ from the baseline results. Thus, we can neither reject nor confirm this hypothesis. Third, confirming $\mathrm{H} 3$, the decreased attractiveness of external debt made companies lower their external rather than their internal debt. The third conclusion, based on the evidence presented above, indicates that the new interest barrier has possibly caused more damage than good. It intended to influence multinationals in such a way that they would reduce their internal debt to assets ratios. The analysis above, however, indicates that first and 
foremost national companies reacted by adjusting their external debt to assets ratio. In defending the interest barrier, one could put forward the argument that the multinationals are affected by the rule by no longer being able to deduct their interest expenses. Given that such firms are very likely to do tax planning, however, such an argument is rather unlikely to hold.

Table 12 in the Appendix presents an additional analysis which splits up the binary variable treated into some of its components. By differencing whether a company is part of a group or has at least one $25 \%$ shareholder, whether it has positive net interest payments, whether it exceeds the general interest allowance and whether its net interest payments exceed $30 \%$ of EBITDA, we can derive which aspects actually drive the firms to adjust their debt to assets ratios facing the new interest barrier. Table 12 in the Annex shows negative and significant coefficients of net int $>0 *$ reform and net int once $>$ $0 *$ reform, meaning that especially firms with more interest expenses than interest earnings reduced their debt to assets ratios after the reform. The negative and significant interaction in column (7) suggests that it also matters for firms' reactions whether the net interest payments exceed the $30 \%$ EBITDA threshold.

Table 13 in the Appendix serves as a general sensivity analysis of the results presented in Table 4. In Table 13, the dependent variable is not the debt to assets ratio, but the net interest payments to assets. This accounts for the firms' possibility to align themselves with the new interest barrier by lowering their charged internal interest rates instead of reducing the debt to assets ratio. As can be seen, the conclusions to be drawn from Table 13 are the same as those from Table 4. Treated firms did not lower their internal net interest payments after the interest barrier introduction. We rather see a reduction of external net interest payments. The positive and significant coefficient of treated $*$ reform for internal debt indicates that treated firms exhibit an increased ratio compared to non-treated firms. This might be due to the fact that treated firms have a low profitability and need more debt to survive. See the discussion of Table 8 for details.

In tracing hypotheses $\mathrm{H} 1$ to $\mathrm{H} 3$, we only made the difference whether a company is hypothetically treated by the interest barrier or not or if it is treated more severely than by the old one. We did not distinguish to what degree such a company may be affected. It is probable that those firms which are denied only a minor amount of interest deductibility, might not consider changing, i.e. lowering, their leverage. As a robustness check, and in order to test hypotheses $\mathrm{H} 4$ and H5, we run additional regressions. In these regressions, we focus on highly leveraged companies and on companies with a low profitability. Analytical reasons for concentrating on these groups have been outlined in Section 3 above. 
Table 7: Regressions comparing highly leveraged companies with other companies

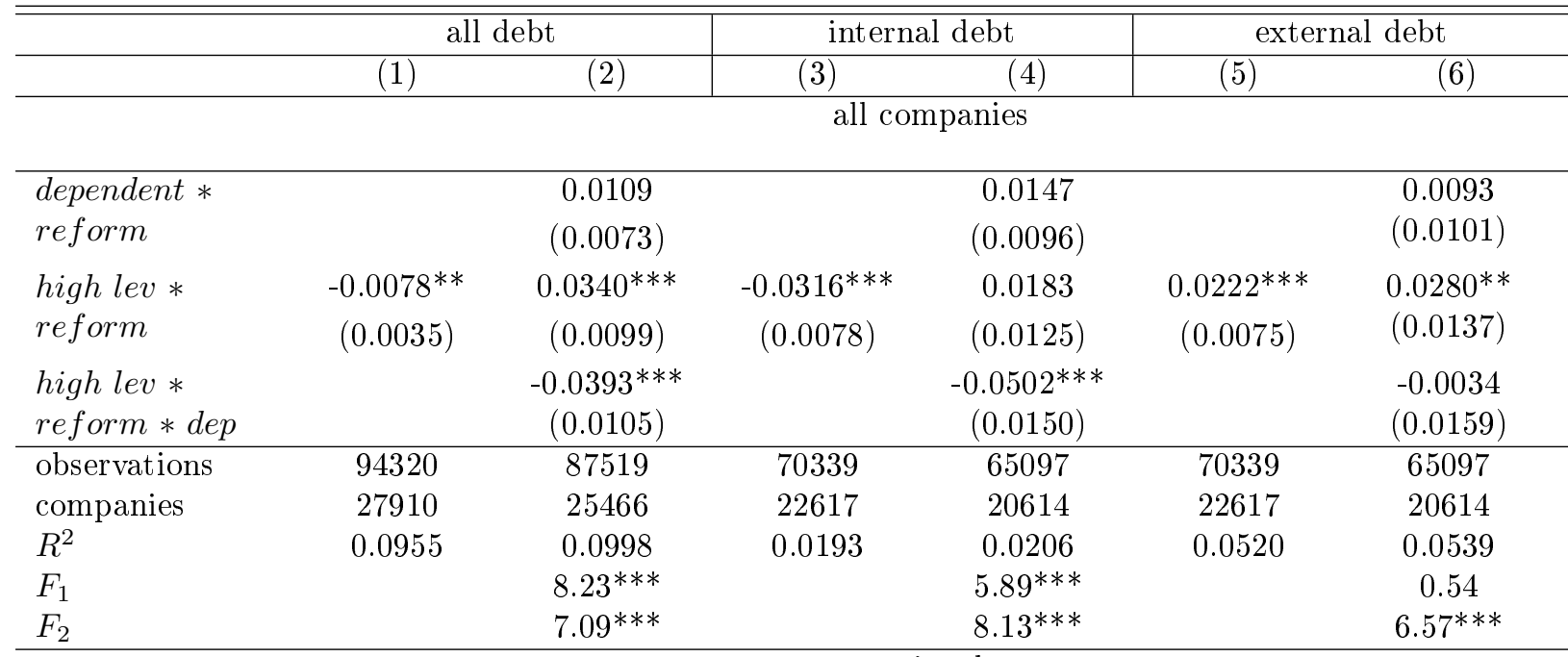

nationals

\begin{tabular}{lcccccc}
\hline $\begin{array}{l}\text { dependent } * \\
\text { reform }\end{array}$ & & 0.0090 & & 0.0133 & & 0.0093 \\
high lev $*$ & $(0.0073)$ & & $(0.0095)$ & & $(0.0102)$ \\
reform & -0.0052 & $0.0337^{* * *}$ & $-0.0307^{* * *}$ & 0.0168 & $0.0244^{* * *}$ & $0.0304^{* *}$ \\
high lev $*$ & $(0.0036)$ & $(0.0100)$ & $(0.0082)$ & $(0.0126)$ & $(0.0079)$ & $(0.0142)$ \\
reform * dep & & $-0.0361^{* * *}$ & & $-0.0480^{* * *}$ & & -0.0032 \\
\hline observations & & $(0.0105)$ & & $(0.0154)$ & & $(0.0165)$ \\
companies & 85156 & 78505 & 61876 & 56779 & 61876 & 56779 \\
$R^{2}$ & 25608 & 23204 & 20398 & 18435 & 20398 & 18435 \\
$F_{1}$ & 0.1027 & 0.1083 & 0.0215 & 0.0231 & 0.0545 & 0.0573 \\
$F_{2}$ & & $7.10^{* * *}$ & & $5.09^{* * *}$ & & 0.52 \\
& & $5.96^{* * *}$ & & $6.84^{* * *}$ & & $7.09^{* * *}$ \\
\hline
\end{tabular}

multinationals

\begin{tabular}{lclclcl}
\hline high lev $*$ & $-0.0401^{* * *}$ & n.a. & -0.0363 & n.a. & -0.0033 & n.a. \\
reform & $(0.0139)$ & n.a. & $(0.0243)$ & n.a. & $(0.0233)$ & n.a. \\
\hline observations & 9164 & n.a. & 8463 & n.a. & 8463 & n.a. \\
companies & 2302 & n.a. & 2219 & n.a. & 2219 & n.a. \\
$R^{2}$ & 0.1090 & n.a. & 0.0618 & n.a. & 0.0893 & n.a. \\
\hline
\end{tabular}

The dependent variable is debt to assets. High lev * reform is an interaction of dummies which equals 1 if the observation is made after the introduction of the interest barrier and the firm is among the $5 \%$ highest leveraged firms defined by the mean of the three years before the reform. Regression 2 compares the effect for independent and dependent firms. A negative sign of the three-way interaction high lev* reform * dep means that the difference between debt to assets before and after the reform is lower for highly leveraged companies than for firms with lower debt, especially if they are dependent and therefore potentially affected by the interest barrier. The list of control variables is the same as in the other tables, the respective results are not reported. Regressions 3 and 4 repeat regressions 1 and 2 using internal debt to assets as the dependent variable, regressions 5 and 6 use external debt to assets. Regressions include company and industry-year-fixed effects. Observations for German corporations between 2005 and 2010 stem from the DAFNE-database. In the first panel we show results for all firms, in the second and third panel we distinguish between national and multinational firms. For multinationals, there is no distinction between independent and dependent firms, as here all multinationals are dependent per definition. $F_{1}$ is the test-statistic for a test of joint significance of dependent $*$ reform and high lev $*$ reform $*$ dep, $F_{2}$ is the test-statistic for a test of joint significance of high lev $*$ reform and high lev $*$ reform $*$ dep. Robust standard errors, clustered at the subsidiary level, are shown in parentheses. ${ }^{*}$ denotes significance at the $10 \%$-level, ${ }^{* *}$ at the $5 \%$-level and ${ }^{* * *}$ at the $1 \%$-level. 
Table 7 aims at testing hypothesis H4, stating that after the introduction of the new interest barrier, especially the $5 \%$ previously most highly leveraged companies reduced their debt to assets ratios. The newly introduced variable high lev distinguishes, whether a firm is among the $5 \%$ most highly leveraged firms in terms of the mean debt to assets ratio in the three years before the reform. The dummy dependent is zero for firms which are independent, i.e. do not belong to a group and have no shareholder holding at least $25 \%$ of the shares. The new interest barrier does not apply to such independent firms. We suppose that the dependent highly leveraged and therefore concerned firms relatively reduced their debt to assets ratios compared to the never affected independent firms.

Table 7 is split into three horizontal sections with results for all companies in the first, national companies in the second and multinationals in the third section. All the control variables of the previous three tables are included in the regressions, but not reported in Table 7. They remained qualitatively very similar to the previous estimations in terms of size, sign and significance. Concentrating on all companies in the upper section of Table 7, we see that the most highly leveraged firms indeed reduced their overall leverage after the reform. This can be seen from the significant coefficient high lev * reform in column (1), amounting to -0.0078 and from the results presented in column (2). The coefficient of the three-way interaction high lev $*$ reform $*$ dep is negative and highly significant, indicating that the reaction to the reform differs not only between highly leveraged companies and firms with a lower debt to assets ratio, but that the difference between these two groups especially depends on the fact if the company is independent and therefore potentially affected by the interest barrier or not. Dependent $*$ reform and high lev * reform * dep are jointly significant, which can be seen from the value of $F_{1}$ in Table 7 . This means that dependent highly leveraged firms relatively decreased their debt to assets ratios after the reform compared to highly leveraged but independent firms. These results confirm hypothesis H4.

The results presented in columns (3) and (4) of Table 7 show that the most highly leveraged firms indeed reduced their internal debt to assets ratio. Thus, by contrast to the general result drawn from Tables 4 to 6 , the most highly leveraged firms seem to show the reaction intended by the interest barrier. The reaction can be identified, however, only for the national firms, as can be seen from the significant coefficients -0.0307 and -0.0480 at the center of Table 7. For multinationals, by contrast, the effect on the internal debt to assets ratio is insignificant. Only the coefficient dealing with the total debt to assets ratio is negative and significant. For such multinational companies, there is no distinction between independent and dependent firms, as here all multinationals are dependent by definition. With regards to external debt, columns (5) and (6) of Table 7 show only 
positive significant coefficients for the crucial variables. These findings suggest that the most highly leveraged firms increased their external debt after the reform compared to companies with lower debt to assets ratios. This result opposes to H3 and H4. Given that we, however, observe a reduction in internal leverage, the increase of external debt might in some sense just compensate this development. Testing the same hypotheses based on the $10 \%$ instead of the $5 \%$ most highly leveraged firms led to qualitatively very similar results.

The weak evidence in Table 7 suggests that at least some highly leveraged firms cut their internal debt to assets ratios, which is in line with the goals of the new interest barrier. However, these results cannot be identified for multinational firms. Based on our findings in Tables 4 to 6 we therefore rely on our previous conclusion that the interest barrier is harmfull especially for firms and kinds of leverage that were not targeted by this new rule.

In Table 8, we aim at testing hypothesis H5, stating that after the introduction of the new interest barrier, especially the least profitable companies reduced their debt to assets ratio. The rationale behind this hypothesis has been outlined in Section 3 and 4. The overall structure of Table 8 is similar to the previous table. The newly introduced binary variable low prof equals one if the considered firm is among the group of firms with the $5 \%$ lowest profitability in terms of the mean profitability in the three years before the reform. Column (1) shows the overall effect. The positive and significant coefficients run in opposition against hypothesis $\mathrm{H} 5$. The least profitable firms have increased their debt to assets ratios. This can be observed both for the national firms and for multinationals. If the firms were supposed to make their leverage decisions solely based on the interest barrier, their behavior is counter-intuitive. From a general point of view, however, the increase in the debt to assets ratio for the least profitable firms is well understandable. Firms with extremely low profitability seem to have other concerns than their interest deductibility. They are in need of financing to keep their business running. Due to a lack of internal funds and a decent attractiveness to equity investors, they necessarily increase their debt. This result is in line with the negative coefficient of the control variable profitability, meaning that more profitable companies have lower debt to assets ratios than low profitable firms.

The results from column (2) of Table 8 reveal an interesting additional aspect. The general positive effect of low prof $*$ reform persists, but the three-way interaction low prof * reform * dep shows negative and significant coefficients of -0.1299 and -0.1343 respectively. As it is also jointly significant with dependent $*$ reform, we can conclude that, 
Table 8: Regressions comparing firms with lowest profitability with other companies

\begin{tabular}{|c|c|c|c|c|c|c|}
\hline & \multicolumn{2}{|c|}{ all debt } & \multicolumn{2}{|c|}{ internal debt } & \multicolumn{2}{|c|}{ external debt } \\
\hline & (1) & $(2)$ & (3) & (4) & $(5)$ & (6) \\
\hline & \multicolumn{6}{|c|}{ all companies } \\
\hline dependent $*$ & & $0.0126^{*}$ & & $0.0192^{* * *}$ & & 0.0077 \\
\hline reform & & $(0.0069)$ & & $(0.0073)$ & & $(0.0100)$ \\
\hline low prof $*$ & $0.0175^{* * *}$ & $0.1487^{* *}$ & -0.0061 & $0.4059^{* * *}$ & $0.0229^{* * *}$ & -0.0061 \\
\hline reform & $(0.0057)$ & $(0.0630)$ & $(0.0066)$ & $(0.0104)$ & $(0.0066)$ & $(0.0119)$ \\
\hline low prof $*$ & & $-0.1299 * *$ & & $-0.4134^{* * *}$ & & $0.0314^{* *}$ \\
\hline reform $*$ dep & & $(0.0633)$ & & $(0.0121)$ & & $(0.0134)$ \\
\hline observations & 92938 & 86247 & 69481 & 64306 & 69481 & 64306 \\
\hline companies & 26880 & 24521 & 21962 & 20010 & 21962 & 20010 \\
\hline$R^{2}$ & 0.0961 & 0.1007 & 0.0183 & 0.0203 & 0.0522 & 0.0542 \\
\hline$F_{1}$ & & $3.41^{* *}$ & & $832.72^{* * *}$ & & $10.03^{* * *}$ \\
\hline$F_{2}$ & & $7.49^{* * *}$ & & $767.71^{* * *}$ & & $6.71^{* * *}$ \\
\hline
\end{tabular}

\begin{tabular}{lcccccc}
\hline $\begin{array}{l}\text { dependent } * \\
\text { reform }\end{array}$ & & 0.0110 & & $0.0179^{* *}$ & & 0.0079 \\
low prof $*$ & $(0.0069)$ & & $(0.0073)$ & & $(0.0101)$ \\
reform & $0.0144^{* *}$ & $0.1508^{* *}$ & -0.0081 & $0.4047^{* * *}$ & $0.0232^{* * *}$ & 0.0028 \\
low prof $*$ & $(0.0060)$ & $(0.0636)$ & $(0.0072)$ & $(0.0111)$ & $(0.0073)$ & $(0.0125)$ \\
reform * dep & & $-0.1343^{* *}$ & & $-0.4141^{* * *}$ & & $0.0237^{*}$ \\
\hline observations & & $(0.0638)$ & & $(0.0130)$ & & $(0.0142)$ \\
companies & 83847 & 77306 & 61079 & 56049 & 61079 & 56049 \\
$R^{2}$ & 24631 & 22312 & 19787 & 17875 & 19787 & 17875 \\
$F_{1}$ & 0.1033 & 0.1092 & 0.0206 & 0.0229 & 0.0546 & 0.0575 \\
$F_{2}$ & & $3.15^{* *}$ & & $684.37^{* * *}$ & & $5.34^{* * *}$ \\
\hline
\end{tabular}

multinationals

\begin{tabular}{lclclcl}
\hline low prof $*$ & $0.0322^{*}$ & n.a. & 0.0089 & n.a. & 0.0147 & n.a. \\
reform & $(0.0168)$ & n.a. & $(0.0155)$ & n.a. & $(0.0166)$ & n.a. \\
\hline observations & 9091 & n.a. & 8402 & n.a. & 8402 & n.a. \\
companies & 2249 & n.a. & 2175 & n.a. & 2175 & n.a. \\
$R^{2}$ & 0.1097 & n.a. & 0.0611 & n.a. & 0.0899 & n.a. \\
\hline
\end{tabular}

The dependent variable is debt to assets. Low prof $*$ reform is an interaction of dummies which equals 1 if the observation is made after the introduction of the interest barrier and the firm is among the group of firms with the $5 \%$ lowest profitability defined by the mean of the three years before the reform. Regression 2 compares the effect for independent and dependent firms. A negative sign of the three-way interaction low prof $*$ reform $*$ dep means that the difference between debt to assets before and after the reform is lower for companies with the lowest profitability than for firms with a higher profitability, especially if they are dependent and therefore potentially affected by the interest barrier. The list of control variables is the same as in the other tables, the respective results are not reported. Regressions 3 and 4 repeat regressions 1 and 2 using internal debt to assets as the dependent variable, regressions 5 and 6 use external debt to assets. Regressions include company and industry-year-fixed effects. Observations for German corporations between 2005 and 2010 stem from the DAFNE-database. In the first panel we show results for all firms, in the second and third panel we distinguish between national and multinational firms. For multinationals, there is no distinction between independent and dependent firms, as here all multinationals are dependent per definition. $F_{1}$ is the test-statistic for a test of joint significance of dependent $*$ reform and low prof $*$ reform $*$ dep, $F_{2}$ is the test-statistic for a test of joint significance of low prof $*$ reform and low prof $*$ reform $*$ dep. Robust standard errors, clustered at the subsidiary level, are shown in parentheses. ${ }^{*}$ denotes significance at the $10 \%$-level, ${ }^{* *}$ at the $5 \%$-level and ${ }^{* * *}$ at the $1 \%$-level. 
among the group of low profitable firms, the dependent firms relatively decreased their debt to assets ratios compared to the independent firms. Therefore, even though the interest barrier does not play the most important role for the low profitable firms overall, it still seems to be considered in the way supposed in hypotheses H5. This cannot be shown for multinational firms, however, because all multinationals are dependent firms. As can be seen from column (4) of Table 8, the positive general effect and the negative interest barrier effect prevail when focusing on the internal debt to assets ratio. The results in columns (5) and (6), indicating an increased external debt to assets ratio for national firms with the lowest profitability, oppose the general hypothesis H3 for these kinds of firms. Concerning external debt, hypothesis $\mathrm{H} 5$ is not confirmed by low profitability firms either. Testing hypothesis H5 based on the $10 \%$ instead of the $5 \%$ least profitable firms led to qualitatively very similar results.

\section{Conclusion}

We have analyzed the impact of the new interest barrier on firms' financing structures. We distinguish between national firms and multinationals and between the effects on internal debt to assets and external debt to assets. The interest barrier has been introduced as of 2008 with the primary purpose of preventing multinationals from abusive tax avoidance by means of cross-border internal loans.

In our general regressions, we find that the interest barrier made firms lower their debt to assets ratios and their net interest payments. Opposing its original intention, it seems to be, however, the national rather than the multinational firms which adjusted their capital structure and it is external rather than internal debt which is reduced. Therefore, at large we conclude that the interest barrier does indeed affect financing decisions, but predominantly not in the intended way and not of the intended firms.

In a robustness check, we find that highly leveraged firms reduce their internal debt to assets ratios. This reaction can, however, only be reliably identified for national firms. It is unclear if, at least, the most likely targeted multinationals were influenced by the new interest barrier in the way intended.

A further robustness check reveals that, as expected, firms which are likely to be subject to the interest barrier because they have a very low profitability tackle the threat of nondeductible interest by relatively reducing their debt to assets ratios. This interest barrier effect, however, is overcompensated by such firms' basic need for debt financing to keep 
their business running. Therefore, in total, low profitable firms relatively increased their leverage after the reform.

All in all, our empirical evidence does not give a positive reference to the new interest barrier rule. The legislator might have focused too much on the, albeit, justified and comprehensible task to counteract excessive and abusive internal lending by a few multinationals. Based on the evidence found in this study, the end may hardly justify the means. Significantly influencing i.e. distorting the financing decisions of companies which were not even aimed at is considerable collateral damage. At the same time, from an empirical point of view, it remains unclear if the unbeloved multinational financing structures could be prevented effectively. 


\section{Appendix}

Table 9: Baseline Regressions, all firms, at least once treated

\begin{tabular}{|c|c|c|c|c|c|c|}
\hline & \multicolumn{2}{|c|}{ all debt } & \multicolumn{2}{|c|}{ internal debt } & \multicolumn{2}{|c|}{ external debt } \\
\hline & (1) & $(2)$ & $(3)$ & $(4)$ & $(5)$ & $(6)$ \\
\hline \multirow{2}{*}{$\begin{array}{l}\text { oncetreated } * \\
\text { reform }\end{array}$} & $-0.0074^{*}$ & & 0.0008 & & $-0.0111^{* *}$ & \\
\hline & $(0.0040)$ & & $(0.0049)$ & & $(0.0051)$ & \\
\hline \multirow{2}{*}{$\begin{array}{l}\text { once stricter } * \\
\text { reform }\end{array}$} & & -0.0077 & & 0.0100 & & $-0.0195^{* * *}$ \\
\hline & & $(0.0058)$ & & $(0.0064)$ & & $(0.0065)$ \\
\hline \multirow[t]{2}{*}{ tangibility } & $0.0323^{*}$ & 0.0370 & -0.0185 & 0.0190 & 0.0378 & 0.0086 \\
\hline & $(0.0189)$ & $(0.0350)$ & $(0.0228)$ & $(0.0409)$ & $(0.0243)$ & $(0.0392)$ \\
\hline \multirow{2}{*}{ profitability } & $-0.1873^{* * *}$ & $-0.1848^{* * *}$ & $-0.0748^{* * *}$ & $-0.1091^{* * *}$ & $-0.1099 * * *$ & $-0.0799^{* * *}$ \\
\hline & $(0.0069)$ & $(0.0116)$ & $(0.0085)$ & $(0.0134)$ & $(0.0081)$ & $(0.0119)$ \\
\hline \multirow{2}{*}{ loss carryforward } & $0.1595^{* * *}$ & $0.1238^{* * *}$ & $0.0281^{* *}$ & $0.0558^{* * *}$ & $0.1077^{* * *}$ & $0.0623^{* * *}$ \\
\hline & $(0.0090)$ & $(0.0150)$ & $(0.0112)$ & $(0.0177)$ & $(0.0111)$ & $(0.0162)$ \\
\hline \multirow{2}{*}{ str $*$ loss carryfwd } & $-0.3836^{* * *}$ & $-0.2859^{* * *}$ & $-0.0546^{*}$ & $-0.1284^{* *}$ & $-0.2628^{* * *}$ & $-0.1409^{* * *}$ \\
\hline & $(0.0261)$ & $(0.0434)$ & $(0.0322)$ & $(0.0510)$ & $(0.0322)$ & $(0.0467)$ \\
\hline \multirow[t]{2}{*}{ str * tangibility } & $-0.1471^{* * *}$ & -0.1061 & $-0.1107^{* *}$ & $-0.1691^{*}$ & -0.0564 & 0.0688 \\
\hline & $(0.0430)$ & $(0.0825)$ & $(0.0559)$ & $(0.0992)$ & $(0.0567)$ & $(0.0921)$ \\
\hline \multirow[t]{2}{*}{ In employees } & $0.0192^{* * *}$ & $0.0211^{* * *}$ & $-0.0085^{* * *}$ & $-0.0081^{*}$ & $0.0274^{* * *}$ & $0.0285^{* * *}$ \\
\hline & $(0.0026)$ & $(0.0038)$ & $(0.0028)$ & $(0.0042)$ & $(0.0028)$ & $(0.0037)$ \\
\hline observations & 95211 & 29649 & 70987 & 27665 & 70987 & 27665 \\
\hline companies & 28213 & 7878 & 22897 & 7661 & 22897 & 7661 \\
\hline$R^{2}$ & 0.0969 & 0.0969 & 0.0184 & 0.0348 & 0.0517 & 0.0533 \\
\hline
\end{tabular}

The dependent variable is debt to assets. Once treated $*$ reform is an interaction of dummies which equals 1 if the observation is made after the introduction of the interest barrier and the firm would have been treated by the new rule at least in one year before the introduction. A negative sign of the coefficient means that the difference between the leverage before and after the reform is lower for treated firms compared to companies not treated by the new interest barrier. In regression 2 we use the interaction once stricter $*$ reform to analyze if firms, for which the new interest barrier would have been stricter than the old rule at least in one year before the reform, reduced their debt to assets ratios more strongly or increased it to a lower extent than other firms. Other variables are described in Table 1. Regressions 3 and 4 repeat regressions 1 and 2 using internal debt to assets as the dependent variable, regressions 5 and 6 use external debt to assets. Regressions include company and industry-year-fixed effects. Observations of German corporations between 2005 and 2010 stem from the DAFNE-database. Robust standard errors, clustered at the subsidiary level, are shown in parentheses. ${ }^{*}$ denotes significance at the $10 \%$-level, ${ }^{* *}$ at the $5 \%$-level and ${ }^{* * *}$ at the $1 \%$-level. 
Table 10: Baseline Regressions, nationals, at least once treated

\begin{tabular}{|c|c|c|c|c|c|c|}
\hline & \multicolumn{2}{|c|}{ all debt } & \multicolumn{2}{|c|}{ internal debt } & \multicolumn{2}{|c|}{ external debt } \\
\hline & $(1)$ & $(2)$ & $(3)$ & $(4)$ & $(5)$ & (6) \\
\hline \multirow{2}{*}{$\begin{array}{l}\text { once treated } * \\
\text { reform }\end{array}$} & -0.0071 & & -0.0021 & & -0.0079 & \\
\hline & $(0.0046)$ & & $(0.0059)$ & & $(0.0062)$ & \\
\hline \multirow{2}{*}{$\begin{array}{l}\text { once stricter } * \\
\text { reform }\end{array}$} & & $-0.0140^{* *}$ & & 0.0029 & & $-0.0184^{* *}$ \\
\hline & & $(0.0070)$ & & $(0.0079)$ & & $(0.0078)$ \\
\hline \multirow[t]{2}{*}{ tangibility } & $0.0330^{*}$ & 0.0475 & -0.0111 & 0.0379 & 0.0299 & -0.0032 \\
\hline & $(0.0193)$ & $(0.0367)$ & $(0.0235)$ & $(0.0443)$ & $(0.0254)$ & $(0.0427)$ \\
\hline \multirow[t]{2}{*}{ profitability } & $-0.1877^{* * *}$ & $-0.1755^{* * *}$ & $-0.0708^{* * *}$ & $-0.1055^{* * *}$ & $-0.1120^{* * *}$ & $-0.0737^{* * *}$ \\
\hline & $(0.0072)$ & $(0.0123)$ & $(0.0091)$ & $(0.0147)$ & $(0.0087)$ & $(0.0131)$ \\
\hline \multirow[t]{2}{*}{ loss carryforward } & $0.1534^{* * *}$ & $0.1272^{* * *}$ & $0.0246^{* *}$ & $0.0599 * * *$ & $0.1048^{* * *}$ & $0.0607 * * *$ \\
\hline & $(0.0094)$ & $(0.0164)$ & $(0.0121)$ & $(0.0204)$ & $(0.0121)$ & $(0.0183)$ \\
\hline \multirow[t]{2}{*}{ str $*$ loss carryfwd } & $-0.3659 * * *$ & $-0.2932^{* * *}$ & -0.0512 & $-0.1498^{* *}$ & $-0.2477^{* * *}$ & $-0.1244^{* *}$ \\
\hline & $(0.0271)$ & $(0.0476)$ & $(0.0348)$ & $(0.0588)$ & $(0.0348)$ & $(0.0527)$ \\
\hline \multirow[t]{2}{*}{ str $*$ tangibility } & $-0.1763^{* * *}$ & $-0.1711^{* *}$ & $-0.1351^{* *}$ & $-0.2246^{* *}$ & -0.0647 & 0.0657 \\
\hline & $(0.0437)$ & $(0.0866)$ & $(0.0578)$ & $(0.1077)$ & $(0.0586)$ & $(0.0994)$ \\
\hline \multirow[t]{2}{*}{ ln employees } & $0.0167^{* * *}$ & $0.0167^{* * *}$ & $-0.0098^{* * *}$ & $-0.0102^{* *}$ & $0.0254^{* * *}$ & $0.0266^{* * *}$ \\
\hline & $(0.0027)$ & $(0.0044)$ & $(0.0030)$ & $(0.0047)$ & $(0.0030)$ & $(0.0041)$ \\
\hline observations & 85889 & 23905 & 62381 & 22098 & 62381 & 22098 \\
\hline companies & 25851 & 6483 & 20622 & 6276 & 20622 & 6276 \\
\hline$R^{2}$ & 0.1042 & 0.1089 & 0.0206 & 0.0427 & 0.0540 & 0.0575 \\
\hline
\end{tabular}

The dependent variable is debt to assets. Once treated * reform is an interaction of dummies which equals 1 if the observation is made after the introduction of the interest barrier and the firm would have been treated by the new rule at least in one year before the introduction. A negative sign of the coefficient means that the difference between the leverage before and after the reform is lower for treated firms compared to companies not affected by the new interest barrier. In regression 2 we use the interaction once stricter * reform to analyze if firms, for which the new interest barrier would have been stricter than the old rule at least in one year before the reform, reduced their debt to assets ratios more strongly or increased it to a lower extent than other firms. Other variables are described in Table 1. Regressions 3 and 4 repeat regressions 1 and 2 using internal debt to assets as the dependent variable, regressions 5 an 6 use external debt to assets. Regressions include company and industry-year-fixed effects. Observations of German corporations not being a member of a multinational group between 2005 and 2010 stem from the DAFNE-database. Robust standard errors, clustered at the subsidiary level, are shown in parentheses. ${ }^{*}$ denotes significance at the $10 \%$-level, ${ }^{* *}$ at the $5 \%$-level and ${ }^{* * *}$ at the $1 \%$-level. 
Table 11: Baseline Regressions, multinationals, at least once treated

\begin{tabular}{|c|c|c|c|c|c|c|}
\hline & \multicolumn{2}{|c|}{ all debt } & \multicolumn{2}{|c|}{ internal debt } & \multicolumn{2}{|c|}{ external debt } \\
\hline & (1) & $(2)$ & $(3)$ & $(4)$ & $(5)$ & $(6)$ \\
\hline \multirow{2}{*}{$\begin{array}{l}\text { once treated } * \\
\text { reform }\end{array}$} & $-0.0213^{* *}$ & & 0.0027 & & $-0.0249 * * *$ & \\
\hline & $(0.0084)$ & & $(0.0092)$ & & $(0.0093)$ & \\
\hline \multirow{2}{*}{$\begin{array}{l}\text { once stricter } * \\
\text { reform }\end{array}$} & & -0.0062 & & 0.0161 & & $-0.0242 * *$ \\
\hline & & $(0.0102)$ & & $(0.0107)$ & & $(0.0113)$ \\
\hline \multirow[t]{2}{*}{ tangibility } & 0.1182 & 0.0251 & -0.0199 & -0.0757 & 0.1022 & 0.0982 \\
\hline & $(0.0852)$ & $(0.1169)$ & $(0.0945)$ & $(0.1219)$ & $(0.0846)$ & $(0.1079)$ \\
\hline \multirow{2}{*}{ profitability } & $-0.1799 * * *$ & $-0.2210^{* * *}$ & $-0.0965^{* * *}$ & $-0.1236^{* * *}$ & $-0.0966^{* * *}$ & $-0.1033^{* * *}$ \\
\hline & $(0.0229)$ & $(0.0311)$ & $(0.0230)$ & $(0.0313)$ & $(0.0213)$ & $(0.0275)$ \\
\hline \multirow{2}{*}{ loss carryforward } & $0.1789^{* * *}$ & $0.1016^{* * *}$ & 0.0362 & 0.0220 & $0.1174^{* * *}$ & $0.0775^{* *}$ \\
\hline & $(0.0310)$ & $(0.0363)$ & $(0.0294)$ & $(0.0347)$ & $(0.0293)$ & $(0.0355)$ \\
\hline \multirow{2}{*}{ str $*$ loss carryfwd } & $-0.4443^{* * *}$ & $-0.2366^{* *}$ & -0.0407 & -0.0015 & $-0.3312^{* * *}$ & $-0.2266^{* *}$ \\
\hline & (0.0901) & $(0.1048)$ & $(0.0853)$ & $(0.1006)$ & $(0.0857)$ & $(0.1035)$ \\
\hline \multirow[t]{2}{*}{ str $*$ tangibility } & -0.0608 & 0.1422 & -0.1221 & 0.0160 & 0.0791 & 0.1029 \\
\hline & $(0.2173)$ & $(0.2853)$ & $(0.2387)$ & $(0.3024)$ & $(0.2170)$ & $(0.2659)$ \\
\hline \multirow[t]{2}{*}{ In employees } & $0.0324^{* * *}$ & $0.0356^{* * *}$ & -0.0045 & -0.0018 & $0.0368^{* * *}$ & $0.0346^{* * *}$ \\
\hline & $(0.0062)$ & $(0.0067)$ & $(0.0075)$ & $(0.0086)$ & $(0.0072)$ & $(0.0083)$ \\
\hline observations & 9322 & 5744 & 8606 & 5567 & 8606 & 5567 \\
\hline companies & 2362 & 1395 & 2275 & 1385 & 2275 & 1385 \\
\hline$R^{2}$ & 0.1110 & 0.1382 & 0.0597 & 0.0800 & 0.0901 & 0.1035 \\
\hline
\end{tabular}

The dependent variable is debt to assets. Once treated $*$ reform is an interaction of dummies which equals 1 if the observation is made after the introduction of the interest barrier and the firm would have been treated by the new rule at least in one year before the introduction. A negative sign of the coefficient means that the difference between the leverage before and after the reform is lower for treated firms compared to companies not affected by the new interest barrier. In regression 2 we use the interaction once stricter $*$ reform to analyze if firms, for which the new interest barrier would have been stricter than the old rule at least in one year before the reform, reduced their debt to assets ratios more strongly or increased it to a lower extent than other firms. Other variables are described in Table 1. Regressions 3 and 4 repeat regressions 1 and 2 using internal debt to assets as the debendent variable, regressions 5 and 6 use external debt to assets. Regressions include company and industry-year-fixed effects. Observations for German corporations being a member of a multinational group between 2005 and 2010 stem from the DAFNE-database. Robust standard errors, clustered at the subsidiary level, are shown in parentheses. ${ }^{*}$ denotes significance at the $10 \%$-level, ${ }^{* *}$ at the $5 \%$-level and ${ }^{* * *}$ at the $1 \%$-level. 


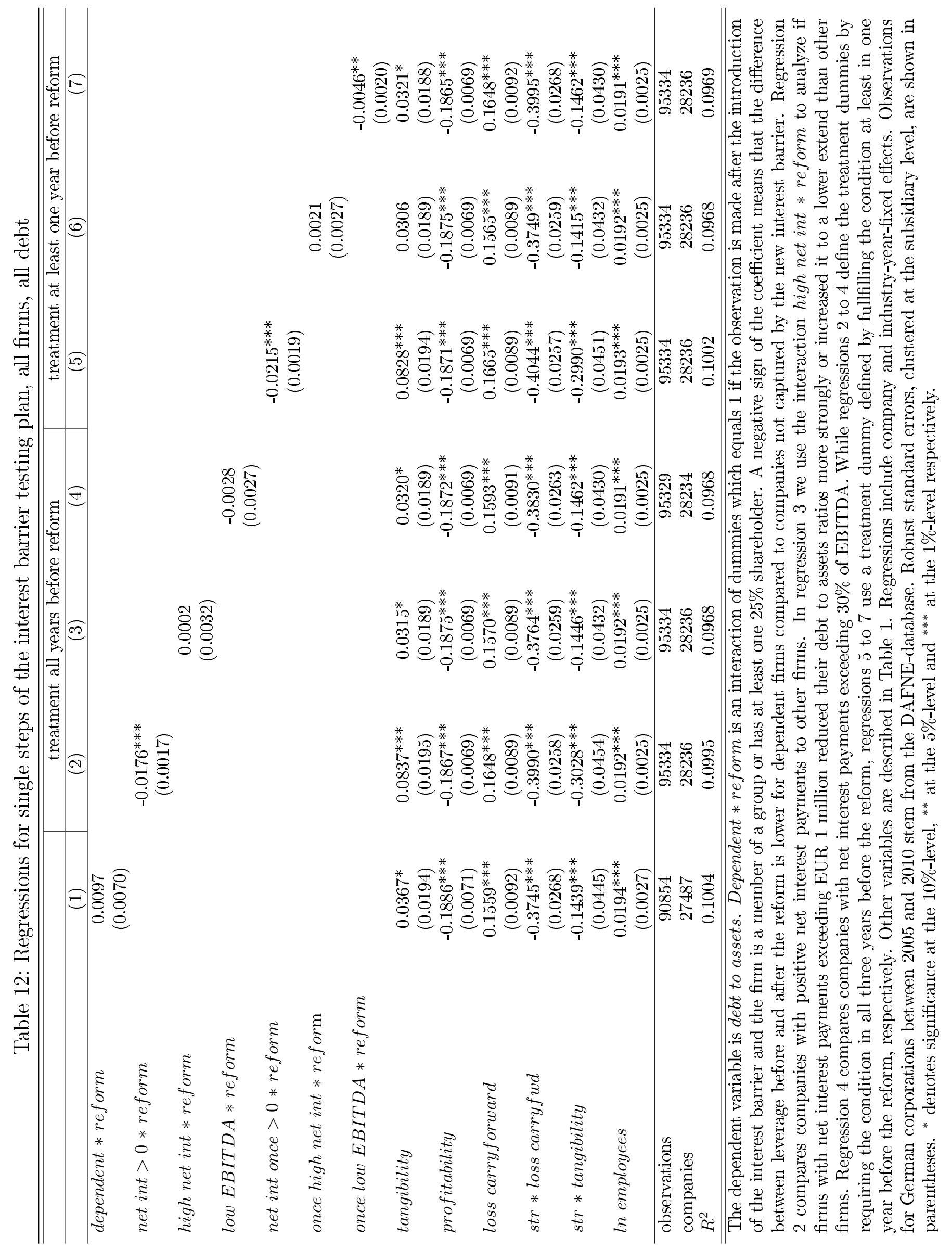


Table 13: Baseline Regressions using net interest payments per assets as dependent variable, all firms

\begin{tabular}{|c|c|c|c|c|c|c|}
\hline & \multicolumn{2}{|c|}{ all net interest payments } & \multicolumn{2}{|c|}{ internal net int. pay. } & \multicolumn{2}{|c|}{ external net int. pay. } \\
\hline & (1) & $(2)$ & $(3)$ & (4) & $(5)$ & $(6)$ \\
\hline treated $*$ reform & $\begin{array}{c}-0.0068^{* * *} \\
(0.0011)\end{array}$ & & $\begin{array}{c}0.0014^{* *} \\
(0.0007)\end{array}$ & & $\begin{array}{c}-0.0084^{* * *} \\
(0.0016)\end{array}$ & \\
\hline stricter $*$ reform & & $\begin{array}{c}-0.0049^{* * *} \\
(0.0011)\end{array}$ & & $\begin{array}{c}0.0012 \\
(0.0008)\end{array}$ & & $\begin{array}{c}-0.0072^{* * *} \\
(0.0017)\end{array}$ \\
\hline tangibility & $\begin{array}{c}0.0148^{* * *} \\
(0.0020)\end{array}$ & $\begin{array}{c}0.0150^{* * *} \\
(0.0034)\end{array}$ & $\begin{array}{c}0.0062 \\
(0.0059)\end{array}$ & $\begin{array}{c}0.0103 \\
(0.0085)\end{array}$ & $\begin{array}{c}0.0069 \\
(0.0077)\end{array}$ & $\begin{array}{c}0.0037 \\
(0.0101)\end{array}$ \\
\hline profitability & $\begin{array}{l}-0.0007 \\
(0.0011)\end{array}$ & $\begin{array}{c}-0.0045^{* * *} \\
(0.0014)\end{array}$ & $\begin{array}{l}-0.0012 \\
(0.0017)\end{array}$ & $\begin{array}{l}-0.0019 \\
(0.0024)\end{array}$ & $\begin{array}{l}-0.0003 \\
(0.0028)\end{array}$ & $\begin{array}{l}-0.0004 \\
(0.0035)\end{array}$ \\
\hline loss carryforward & $\begin{array}{l}0.0031^{* *} \\
(0.0013)\end{array}$ & $\begin{array}{c}0.0004 \\
(0.0018)\end{array}$ & $\begin{array}{c}0.0019 \\
(0.0017)\end{array}$ & $\begin{array}{c}0.0012 \\
(0.0022)\end{array}$ & $\begin{array}{l}-0.0026 \\
(0.0029)\end{array}$ & $\begin{array}{l}-0.0014 \\
(0.0037)\end{array}$ \\
\hline str $*$ loss carryfwd & $\begin{array}{l}-0.0026 \\
(0.0037)\end{array}$ & $\begin{array}{c}0.0060 \\
(0.0051)\end{array}$ & $\begin{array}{l}-0.0042 \\
(0.0049)\end{array}$ & $\begin{array}{l}-0.0027 \\
(0.0063)\end{array}$ & $\begin{array}{c}0.0117 \\
(0.0083)\end{array}$ & $\begin{array}{c}0.0098 \\
(0.0103)\end{array}$ \\
\hline str $*$ tangibility & $\begin{array}{c}0.0148^{* * *} \\
(0.0051)\end{array}$ & $\begin{array}{c}0.0102 \\
(0.0079)\end{array}$ & $\begin{array}{l}-0.0275^{*} \\
(0.0141)\end{array}$ & $\begin{array}{l}-0.0316 \\
(0.0199)\end{array}$ & $\begin{array}{c}0.0526^{* * *} \\
(0.0181)\end{array}$ & $\begin{array}{c}0.0534^{* *} \\
(0.0240)\end{array}$ \\
\hline ln employees & $\begin{array}{c}0.0006^{* *} \\
(0.0002)\end{array}$ & $\begin{array}{c}0.0003 \\
(0.0004)\end{array}$ & $\begin{array}{c}-0.0007^{* *} \\
(0.0003)\end{array}$ & $\begin{array}{c}-0.0008^{*} \\
(0.0004)\end{array}$ & $\begin{array}{l}0.0009^{*} \\
(0.0005)\end{array}$ & $\begin{array}{c}0.0009 \\
(0.0006)\end{array}$ \\
\hline observations & 88333 & 29631 & 29225 & 17829 & 29225 & 17829 \\
\hline companies & 25746 & 7877 & 10077 & 5653 & 10077 & 5653 \\
\hline$R^{2}$ & 0.0594 & 0.0497 & 0.0385 & 0.0315 & 0.0777 & 0.0525 \\
\hline
\end{tabular}

The dependent variable is net interest payments to assets. Treated * reform is an interaction of dummies which equals 1 if the observation is made after the introduction of the interest barrier and the firm would have been treated by the new rule in all three years before the introduction. A negative sign of the coefficient means that the difference between the net interest payments before and after the reform is lower for treated firms compared to companies not affected by the new interest barrier. In regression 2 we use the interaction stricter * reform to analyze if firms, for which the new interest barrier would have been stricter than the old rule in all three years before the reform, reduced their net interest payments to assets ratios more strongly or increased it to a lower extend than other firms. Other variables are described in Table 1. Regressions 3 and 4 repeat regressions 1 and 2 using internal debt to assets as the dependent variable, regressions 5 and 6 use external debt to assets. Regressions include company and industry-year-fixed effects. Observations for German corporations between 2005 and 2010 stem from the DAFNE-database. Robust standard errors, clustered at the subsidiary level, are shown in parentheses. * denotes significance at the $10 \%$-level, ${ }^{* *}$ at the $5 \%$-level and ${ }^{* * *}$ at the $1 \%$-level. 


\section{References}

Alworth, J. and G. Arachi (2001): The effect of taxes on corporate financing decisions: Evidence from a panel of Italian firms, International Tax and Public Finance 8, p. 353 376.

Bach, S. and H. Buslei (2009): Zinsschranke trifft vor allem Grossunternehmen, DIW-Wochenbericht 76, p. 283 - 287.

Blaufus, K. and D. Lorenz (2009): Die Zinsschranke in der Krise, Steuer und Wirtschaft 86, p. $323-332$.

Blaufus, K. and D. Lorenz (2009): Wem droht die Zinsschranke? Eine empirische Untersuchung zur Identifikation der Einflussfaktoren, Zeitschrift für Betriebswirtschaft 79 , p. $503-526$.

Bolik, A., C. Fuest and M. Ortmann-Babel (2010): Studie zur Evaluation der Gegenfinanzierung der Unternehmensteuerreform 2008, Ernst \& Young GmbH.

BR-Drucksache 220/07 (2007): Gesetzentwurf der Bundesregierung, Entwurf eines Unternehmensteuerreformgesetzes 2008.

Buettner, T., M. Overesch, U. Schreiber und G. Wamser (2008): The Impact of Thin Capitalization Rules on Multinationals' Financing and Investment Decisions, Bundesbank Discussion Paper 03/2008, Frankfurt.

Desai, M.A., C.F. Foley and J.R. Hines (2004): A multinational perspective on capital structure choice and internal capital markets, Journal of Finance 59, p. 2451 - 2487.

Dörfler, H. and A. Vogl (2007): Unternehmensteuerreform 2008: Auswirkungen der geplanten Zinsschranke anhand ausgewählter Beispiele, Betriebs Berater 62, p. 1084 1087.

Dourado, A.P. and R. de la Feria (2008): Thin capitalization rules in the context of the $C C C T B$, Oxford University Centre for Business Taxation Working Paper 08/04.

Eilers, S. (2007): Fremdfinanzierung im Unternehmen nach der

Unternehmensteuerreform 2008, Finanzrundschau 89, p. 733 - 735.

Endres, D. (2007): Auswirkungen der Zinsschranke auf die Gesellschafter-Fremdfinanzierung, Praxis Internationale Steuerberatung, p. 230 - 235.

Feld, L., J. Heckemeyer and M. Overesch (2011): Capital Structure Choice and Company Taxation: A Meta-Study, CESifo Working Paper No. 3400, Munich.

Führich, G. (2007): Ist die geplante Zinsschranke europarechtskonform? Internationales Steuerrecht, p. $341-345$. 
Ganssauge, K. and O. Mattern (2008): Der Eigenkapitaltest im Rahmen der Zinsschranke, Deutsches Steuerrecht, p. 213 - 219 and p. $267-270$.

Gordon, R. and Y. Lee (2001): Do taxes affect corporate debt policy? Evidence from U.S. corporate tax return data, Journal of Public Economics 82, p. 195 - 224.

Gordon, R. and Y. Lee (2007): Interest rates, taxes and corporate financial policies, National Tax Journal 60, p. $65-84$.

Graham, J.R. (1999): Do personal taxes affect corporate financing decisions?, Journal of Public Economics 73, p. 147 - 185.

Graham, J.R. (2003): Taxes and corporate finance: A review, Review of Financial Studies 16, p. 1075 - 1129.

Grotherr, S. (2008): Funktionsweise und Zweifelsfragen der neuen Zinsschranke, Internationale Wirtschafts-Briefe 07, p. 1489 - 1508.

Haufler, A. and M. Runkel (2008): Firms' financial choices and thin capitalization rules under corporate tax competition, CESifo Working Paper No. 2429, Munich.

Herzig, N. and A. Bohn (2007): Modifizierte Zinsschranke und Unternehmensfinanzierung, Der Betrieb 60, p. 1 - 10.

Herzig, N., U. Lochmann and B. Liekenbrock (2008): Die Zinsschranke im Lichte einer Unternehmensbefragung. Einfluss auf Steuerplanung, Steuergestaltung und Steuerbelastung, Der Betrieb 61, p. 593 - 602.

Herzig, N. and B. Liekenbrock (2010): Zum EBITDA-Vortrag der Zinsschranke, Der Betrieb, p. 690 - 695.

Hey, J. (2007): Verletzung fundamentaler Besteuerungsprinzipien durch die Gegenfinanzierungsmassnahmen des Unternehmenssteuerreformgesetzes 2008, Betriebs-Berater 62, p. 1303 - 1309.

Homburg, S. (2007): Die Zinsschranke - eine beispiellose Steuerinnovation, Finanzrundschau 89, p. 717 - 728.

Homburg, S., H. Houben and R. Maiterth (2007): Rechtsform und Finanzierung nach der Unternehmensteuerreform 2008, Die Wirtschaftsprüfung 60, p. 376 - 381.

Hornig, M. (2007): Die Zinsschranke - ein europarechtlicher Irrweg, Praxis Internationale Steuerberatung, p. 215 - 220.

Huizinga, H., L. Laeven and G. Nicodème (2008): Capital structure and international debt shifting, Journal of Financial Economics 88, p. 80 - 118.

Köhler, S. (2007): Erste Gedanken zur Zinsschranke nach der Unternehmensteuerreform, in: Deutsches Steuerrecht 45, p. 597 - 604. 
Lemmon, M.L., M.R. Roberts and J.F. Zender (2008): Back to the beginning: persistence and the cross-section of corporate capital structure, Journal of Finance 63, p. $1575-1608$.

Lenz, M., O. Doerfler and G. Adrian (2010): Änderungen bei der Zinsschranke durch das Wachstumsbeschleunigungsgesetz, Die Unternehmensbesteuerung, p. 1 - 7.

MacKie-Mason, J.K. (1990): Do taxes affect corporate financing decisions?, Journal of Finance 45, p. 1471 - 1493.

Miller, M. (1977): Debt and taxes, Journal of Finance 32, p. 261-275.

Modigliani, F. and M. Miller (1958): The cost of capital, corporation finance, and the theory of investment, American Economic Review 48, p. 261 - 297.

Modigliani, F. and M. Miller (1963): Corporate income taxes and the cost of capital: a correction, American Economic Review 53, p. 433 - 443.

Musil, A. and B. Volmering (2008): Systematische, verfassungsrechtliche und europarechtliche Probleme der Zinsschranke, Der Betrieb 1, p. 12 - 16.

Myers, S. C. (1977): Determinants of corporate borrowing, Journal of Financial Economics 5, p. 147 - 175.

Myers, S. C. (1984): The capital structure puzzle, Journal of Finance 39, p. 575 - 592.

Overesch, M. and D. Voeller (2010): The Impact of Personal and Corporate Taxation on Capital Structure Choices, Public Finance Analysis 66, p. 263 - 294.

Pasedag, A. (2010): Paradoxe Wirkungen der Zinsschranke, Corporate Finance biz 12/5, p. $301-311$.

Piltz, D.J. (1996): International aspects of thin capitalization, IFA general report vol. LXXXIb, Rotterdam 1996, p. 19 - 81.

Rajan, R.G. and L. Zingales (1995): What do we know about capital structure? Some evidence from international data, Journal of Finance 50, p. 1421 - 1460.

Rödder, T. and I. Stangl (2007): Zur geplanten Zinsschranke, Der Betrieb, p. 479 - 485.

Rödding, A. (2009): Änderungen der Zinsschranke durch das

Wachstumsbeschleunigungsgesetz, Deutsches Steuerrecht, p. 2649 - 2651.

Schwarz, P. (2008): Zur Notwendigkeit einer Zinsschranke: Empirische Befunde und Probleme, Internationales Steuerrecht 1, p. 11 - 14.

Taub, A.J. (1975): Determinants of firm's capital structure, Review of Economics and Statistics 57, p. 410 - 416. 
Thiel, J. (2007): Die Steuerliche Behandlung von Fremdfinanzierungen im Unternehmen, Finanzrundschau 89, p. 729 - 733.

Thoemmes, O., R. Stricof and K. Nakhai (2004): Thin Capitalization Rules and Non-Discrimination Principles, International Tax Review, p. 126 - 137.

Töben, T. (2007): Die Zinsschranke - Befund und Kritik, Finanzrundschau 89, p. 739 746.

Wamser, G. (2008): The Impact of Thin capitalization Rules on External Debt Usage A Propensity Score Matching Approach, ifo Working Paper No. 62.

Weichenrieder, A. and H. Windischbauer (2008): Thin Capitalization Rules and Company Responses, CESifo Working Paper No. 2456, Munich.

Winkeljohann, N. and S. Fuhrmann (2007): Grundprinzipien der Zinsschranke, in: Die Unternehmenssteuerreform 2008, PwC, Stuttgart, p. 76 - 120.

Welling, B. (2007): Die Zinsschranke. Übersteigerte politische Zielvorgabe an eine Neuordnung der Regelungen zur Gesellschafter Fremdfinanzierung, Finanzrundschau 89, p. 735 - 739 . 